\title{
Functional characterization of cellulases identified from the cow rumen fungus Neocallimastix patriciarum W5 by transcriptomic and secretomic analyses
}

\author{
Tzi-Yuan Wang ${ }^{1+}$, Hsin-Liang Chen ${ }^{1 \dagger}$, Mei-Yeh J Lu ${ }^{1,2+}$, Yo-Chia Chen ${ }^{3 \dagger}$, Huang-Mo Sung ${ }^{4}$, Chi-Tang Mao ${ }^{1,5,6}$, \\ Hsing-Yi Cho ${ }^{5,6,7}$, Huei-Mien Ke ${ }^{1,8}$, Teh-Yang Hwa², Sz-Kai Ruan ${ }^{1}$, Kuo-Yen Hung ${ }^{2}$, Chih-Kuan Chen ${ }^{2,9}$, Jeng-Yi Li ${ }^{2}$, \\ Yueh-Chin Wu' ${ }^{2}$, Yu-Hsiang Chen ${ }^{2}$, Shao-Pei Chou' ${ }^{2}$, Ya-Wen Tsai ${ }^{1}$, Te-Chin Chu ${ }^{10,11}$, Chun-Chieh A Shih ${ }^{10}$, \\ Wen-Hsiung Li $i^{1,5,12,13^{*}}$ and Ming-Che Shih ${ }^{5,7,12^{*}}$
}

\begin{abstract}
Background: Neocallimastix patriciarum is one of the common anaerobic fungi in the digestive tracts of ruminants that can actively digest cellulosic materials, and its cellulases have great potential for hydrolyzing cellulosic feedstocks. Due to the difficulty in culture and lack of a genome database, it is not easy to gain a global understanding of the glycosyl hydrolases (GHs) produced by this anaerobic fungus.

Results: We have developed an efficient platform that uses a combination of transcriptomic and proteomic approaches to N. patriciarum to accelerate gene identification, enzyme classification and application in rice straw degradation. By conducting complementary studies of transcriptome (Roche 454 GS and Illumina GA IIx) and secretome (ESI-Trap LC-MS/MS), we identified 219 putative GH contigs and classified them into 25 GH families. The secretome analysis identified four major enzymes involved in rice straw degradation: $\beta$-glucosidase, endo-1,4- $\beta$ xylanase, xylanase $B$ and Cel48A exoglucanase. From the sequences of assembled contigs, we cloned 19 putative cellulase genes, including the GH1, GH3, GH5, GH6, GH9, GH18, GH43 and GH48 gene families, which were highly expressed in N. patriciarum cultures grown on different feedstocks.

Conclusions: These GH genes were expressed in Pichia pastoris and/or Saccharomyces cerevisiae for functional characterization. At least five novel cellulases displayed cellulytic activity for glucose production. One $\beta$-glucosidase (W5-16143) and one exocellulase (W5-CAT26) showed strong activities and could potentially be developed into commercial enzymes.
\end{abstract}

Keywords: anaerobic fungi, biomass, rice straw, sugarcane, napiergrass, GH, next-generation sequencing

\section{Background}

Cellulosic ethanol produced by microbial fermentation from feedstocks has been proposed to replace fossil fuels in transportation. A key step in cellulosic ethanol production is to break down cellulose into glucose and

\footnotetext{
* Correspondence: whli@uchicago.edu; mcshih@gate.sinica.edu.tw

+ Contributed equally

${ }^{1}$ Biodiversity Research Center, Academia Sinica, Taipei 115, Taiwan

${ }^{5}$ Molecular and Biological Agricultural Sciences Program, Taiwan International Graduate Program, National Chung-Hsing University - Academia Sinica,

Taipei 115, Taiwan

Full list of author information is available at the end of the article
}

hemicellulose into xylose, which can subsequently be converted into ethanol by fermentative microbes. Therefore, finding efficient cellulases is important to bioethanol production, as well as for hydrolyzing feedstocks into sugars in general. Neocallimastix species is one of the major anaerobic fungi in the rumen of water buffalo capable of efficiently digesting cellulosic biomass [1-4]. Such anaerobic fungi are potential sources for highly active cellulolytic enzymes that are useful for cellulose hydrolysis [5-7]. Plant cell wall degrading enzymes from rumen fungi such as Neocallimastix patriciarum may be

\section{Biomed Central}


used for the production of industrial materials from plant biomass. These enzymes may also improve the fiber properties of cotton for manufacturing or clothes. The simple sugars which retain the chemical energy of lignocellulose are easily separated from the digestion products and more readily usable for animal or human food or for the production of chemicals and biofuels [7]. Pai et al. [8] reported the cloning from $N$. patriciarum of a bifunctional xylanolytic enzyme with acetylxylan esterase and xylanase activities. Interestingly, this enzyme contains a double-dockerin domain, suggesting that it is a cellulosomal component and may bind tightly to the cellulosome [8].

Microbial genomes often contain a substantial number of glycosyl hydrolase $(G H)$ genes, many of which respond to different carbon sources. There are many cellulases, such as xylanase and glycosidase, identified in rumen fungi; however, only a fraction of these exocellulases and $\beta$-glucosidases (BGLUs) have shown high enzymatic activities [9-18]. The concentration of extracellular cellulase proteins of $N$. patriciarum W5 detected in our laboratory was about 138.2 to $193.7 \mathrm{mg} /$ L, of which $30 \%$ showed xylanase activity. However, there is no feasible method for long-term preservation of rumen fungal cultures. Anaerobic fungal isolates have to be transferred every two to six days to maintain their activity [19]. To overcome this limitation, previous studies using traditional genetic screening approaches identified several cellulase-related genes from $N$. patriciarum and expressed them in Escherichia coli [8,20-28]. For example, the cellulobiohydrolase of $N$. patriciarum showed a 1,000 times greater specific activity than that of the cellulobiohydrolase of Trichoderma reesei [23]. Such higher cellulase activity can significantly reduce the cost of the desaccharification during cellulosic ethanol production. However, the conventional methods for identifying microbial cellulase genes through purification of cellulosic proteins and/or protein sequence-based cDNA cloning were tedious and time-consuming.

Recent advances in genomics, transcriptomics and proteomics technologies make hunting for cellulase genes much more efficient. Proteomics analysis using liquid chromatography coupled with tandem mass spectrometry (LC-MS/MS) can be used to develop native protein databases that depict the nature and levels of proteins expressed in microbes $[29,30]$. Without a closely related protein sequence database, however, one cannot survey the novel microbial protein profile comprehensively, and full-length sequence information of these proteins for further characterization is required, especially for enzymes present as gene families. In contrast, high-throughput next-generation sequencing can provide abundant cDNA information by using long-read transcriptome sequencing by GS FLX Sequencer (454
Life Sciences/Roche, Branford, CT, USA), and subsequently protein sequences can be derived and used as references for proteomic mapping, enabling the functional profiling of protein diversity and quantification. In parallel, the levels of gene expression can be examined by short-read deep sequencing using Genome Analyzer IIx (Illumina Inc., San Diego, CA, USA). Therefore, proteomic and transcriptomic data can offer complementary information in the hunt for valuable cellulase genes. Here we demonstrate how a combination of omics approaches helped us to identify glycosyl hydrolase $(G H)$ gene families and functional proteins from a nonmodel organism, $N$. patriciarum W5 strain.

In this report, we describe the characterization of several cellulosic genes from the newly isolated $N$. patriciarum W5 strain by complementary secretome and transcriptome analyses. We cultured the W5 strain in different cellulosic substrates such as rice straw, napiergrass and sugarcane powder to enrich cellulase protein expression, and we purified extracellular proteins exhibiting dominant cellulase activity by both enzymatic assays and zymograms. These major cellulase proteins were then identified by LC-MS/MS analysis and online GH family database surveys. The secretome data successfully hit 25 GH family protein sequences. In parallel, the enriched transcriptomes were sequenced for global gene identification. By combining these two omics data, we successfully identified 19 major extracellular cellulase genes of N. patriciarum and cloned them in two yeast expression systems for functional characterization.

\section{Results and Discussion}

\section{Extracellular cellulases of $N$. patriciarum W5}

To stimulate the $N$. patriciarum W5 strain to produce cellulosic enzymes, we used powders of rice straw, napiergrass and sugarcane bagasse. All three cultures had the highest total cellulase activities on day 3 or 4 during the time course assayed by 4-methylumbelliferyl$\beta$-cellobiose (4-MUC) analysis (data not shown). To examine the different cellulase enzymatic activities, we collected the total extracellular proteins (supernatant) at day 4 for further analyses. We assayed the cellulase activities using 4-MUC, $p$-nitrophenyl $\beta \beta$-D-glucopyranoside ( $p$ NPG) and dye CM-cellulose (dye-CMC) as substrates and performed cross-analyses to determine the levels of exoglucanase (EXG), endoglucanase (EG) and BGLU activities in the total extracellular protein extracts (see Methods). We used the following rules to examine EXG, EG and BGLU activities: 4-MUC assays for broad quantitative assays of cellulase activity, dye-CMC assays for EG activity and $p$ NPG assays for BGLU activity. If both dye-CMC and $p$ NPG activities were low, the 4MUC activity was taken to represent the exocellulase activity. Our results showed that the cultures grown in 
rice straw produced the highest extracellular EXG and BGLU activities, and the cultures grown in sugarcane bagasse exhibited the highest endocellulase activity (Figure 1).

\section{Cellulolytic enzyme induction in N. patriciarum W5 by different substrates}

The exo-type cellulolytic activities increased with time to the highest level on the third and fourth days after $N$. patriciarum W5 was induced by different carbon sources (data not shown). The fourth-day culture broth was centrifuged, and the crude enzyme solution was prepared by collecting the supernatant for further analyses of enzyme activities and secretome. The cellulolytic activities of crude enzymes were determined using 4MUC, dye-CMC and $p$ NPG as substrates. As shown in Figure 1, feedstock of plant origins such as napiergrass, sugarcane bagasse and rice straw demonstrate a better induction effect to the cellulase production of N. patriciarum W5 than commercial substrates. The highest activities of EXG and BGLU were found in the broth supplemented by rice straw, whereas the crude enzyme induced by sugarcane bagasse exhibited the highest EG
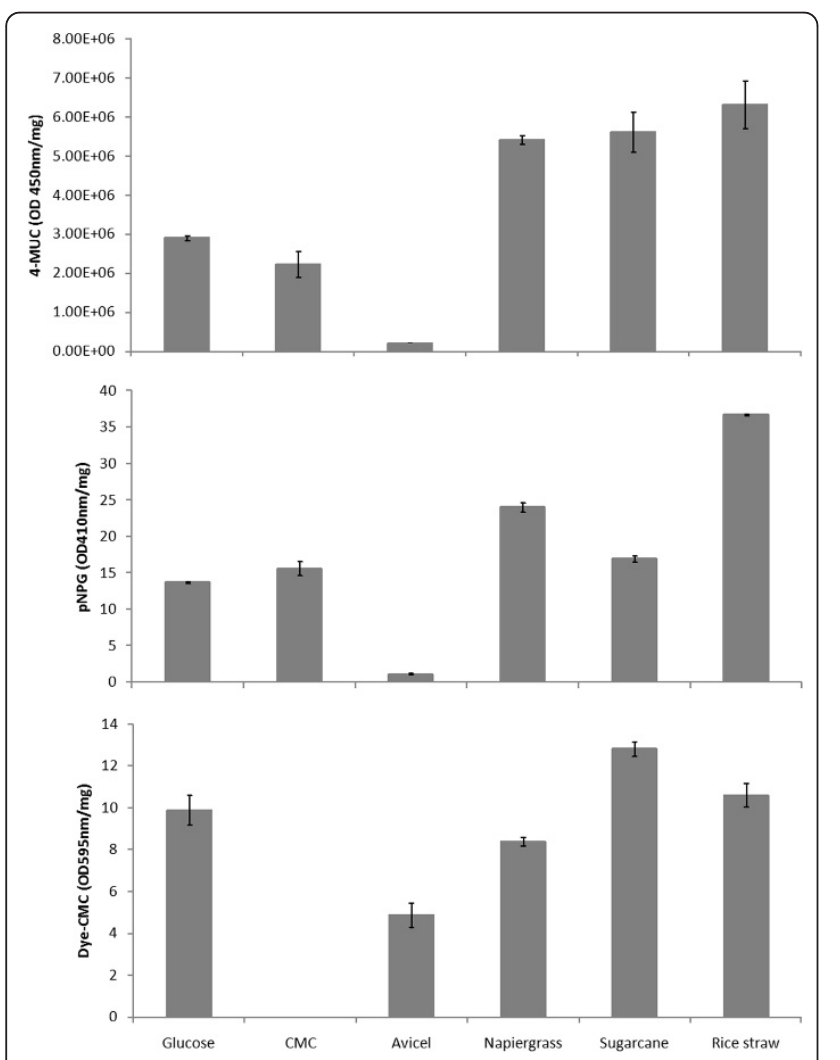

Figure 1 Total cellulase activity of four-day culture of W5 strain in response to glucose, two artificial celluloses (CMC and avicel) and three feedstocks (napiergrass, sugarcane and rice straw). among tested substrates. Rice straw was able to induce the best activities of cellulytic enzymes and was selected as an inducer for the following analyses.

\section{Secretome analysis of $N$. patriciarum W5}

To gather more information on cellulase proteins and eliminate interference of other proteins, we enriched and purified the extracellular cellulase proteins from W5 cultures grown on rice straw-containing medium as shown in Figure 1. To purify the extracellular cellulases, the proteins in condensed supernatants were first subjected to anion exchange chromatography (HiPrep ${ }^{\mathrm{TM}}$ 16/ 10 QFF, GE Healthcare Bio-Sciences AB, Uppsala, Sweden) and then by size exclusion (HiLoad ${ }^{\mathrm{TM}}$ Superdex ${ }^{\mathrm{TM}}$ 200 prep grade Column, GE Healthcare Bio-Sciences $\mathrm{AB}$, Uppsala, Sweden) at $4^{\circ} \mathrm{C}$. After these two steps, the specific activities for 4-MUC, $p$ NPG and dye-CMC were 78.97, 2.17 and $1.15 \mathrm{U} / \mathrm{mg}$, respectively (Table 1). Accordingly, the P2 fraction gathered most purified cellulase proteins by 1.9- to 4.7 -fold (purification factor) compared to the supernatants. The purified cellulases were further fractionated into two major groups with different protein sizes (P2-1 and P2-2 in Figure 2). The dye-CMC assay indicated that these two major fractions both contained EG activity, and the 4-MUC and $p$ NPG assays indicated that both fractions contained EXG as well as BGLU activity. These data suggest that there are at least two sizes of EG and one size each of EXG and BGLU.

To demonstrate that these partially purified proteins were indeed cellulases, we conducted zymogram analysis by CMC blot assay (Figure 3). Our results show that the $N$. patriciarum cultures were induced to express various sizes of putative EG/BGLU (ranging from 20 to 170 $\mathrm{kDa}$ ), but only one major size of putative EXG/BGLU (around $55 \mathrm{kDa}$ ) was found in the 4-MUC zymogram assay. These data were consistent with the fractionation data. Based on the zymogram blot analysis, a total of 17 bands in PAGE were selected from three different batch cultures and subsequently analyzed by ESI-Trap LCMS/MS and a BLAST homology search using the MASCOT online database (see Additional file 1). The peptide sequences generated from MS/MS spectra were successfully mapped to $24 \mathrm{GH}$ genes, including five endocellulases, twelve exocellulases and seven BGLUs from three genera of rumen fungi: Neocallimastix, Orpinomyces and Piromyces. The mass data showed that the protein sequences of the Cel48A, Cel9A and BGLU precursors as well as BGLU Cel1C from Piromyces sp. E2 were frequently mapped by $25,12,43$ and 28 different peptides, respectively. In addition, another BGLU from Orpinomyces sp. PC-2 was also highly mapped by 27 different peptides, and there were 4 endocellulases found in the mass data. The most significant hit, a GUNB_NEOPA 
Table 1 Purified cellulase activity in culture with rice straw ${ }^{\mathrm{a}}$

\begin{tabular}{|c|c|c|c|c|c|}
\hline & $\begin{array}{c}\text { Culture } \\
\text { supernatant }\end{array}$ & $\begin{array}{c}\text { Concentration + buffer } \\
\text { exchange }\end{array}$ & $\begin{array}{l}\text { QFF anion } \\
\text { exchange }\end{array}$ & $\begin{array}{l}\text { S200 gel filtration } \\
\text { P1 }\end{array}$ & $\begin{array}{c}\text { S200 gel filtration } \\
\text { P2 }\end{array}$ \\
\hline Fraction volume, $\mathrm{mL}$ & 500 & 3 & 4 & 1 & 1 \\
\hline Total protein, mg & 27.81 & 8.97 & 2.24 & 1.39 & 0.23 \\
\hline \multicolumn{6}{|l|}{ 4-MUC } \\
\hline Total activity, U & 470.71 & 196.33 & 67.21 & 26.17 & 17.94 \\
\hline $\begin{array}{l}\text { Specific activity, U/ } \\
\text { mg }\end{array}$ & 16.93 & 21.90 & 29.95 & 18.89 & 78.97 \\
\hline Yield, \% & $100 \%$ & $42 \%$ & $14 \%$ & $6 \%$ & $4 \%$ \\
\hline Purification factor & 1.0 & 1.3 & 1.8 & 1.1 & 4.7 \\
\hline \multicolumn{6}{|l|}{ pNPG } \\
\hline Total activity, U & 22.54 & 5.57 & 1.91 & 0.86 & 0.49 \\
\hline $\begin{array}{l}\text { Specific activity, U/ } \\
\text { mg }\end{array}$ & 0.81 & 0.62 & 0.85 & 0.62 & 2.17 \\
\hline Yield, \% & $100 \%$ & $25 \%$ & $8 \%$ & $4 \%$ & $2 \%$ \\
\hline Purification factor & 1.0 & 0.8 & 1.1 & 0.8 & 2.7 \\
\hline \multicolumn{6}{|l|}{ dye-CMC } \\
\hline Total activity, U & 16.79 & 3.36 & 0.78 & 0.07 & 0.26 \\
\hline $\begin{array}{l}\text { Specific activity, U/ } \\
\text { mg }\end{array}$ & 0.60 & 0.38 & 0.35 & 0.05 & 1.15 \\
\hline Yield, \% & $100 \%$ & $20 \%$ & $5 \%$ & $0 \%$ & $2 \%$ \\
\hline Purification factor & 1.0 & 0.6 & 0.6 & 0.1 & 1.9 \\
\hline
\end{tabular}

4-MUC: 4-methylumbelliferyl- $\beta$-cellobiose; dye-CMC: dye CM-cellulose; $p$ NPG: $p$-nitrophenyl- $\beta$-D-glucopyranoside;

EG B precursor, was mapped by seven different peptide sequences. These results suggest that at the time of harvesting, the culture might have a higher abundance of BGLUs than other cellulases. However, there were a few peptides matched with exocellulases, possibly due to the low abundance proteins and/or insufficient rumen fungi

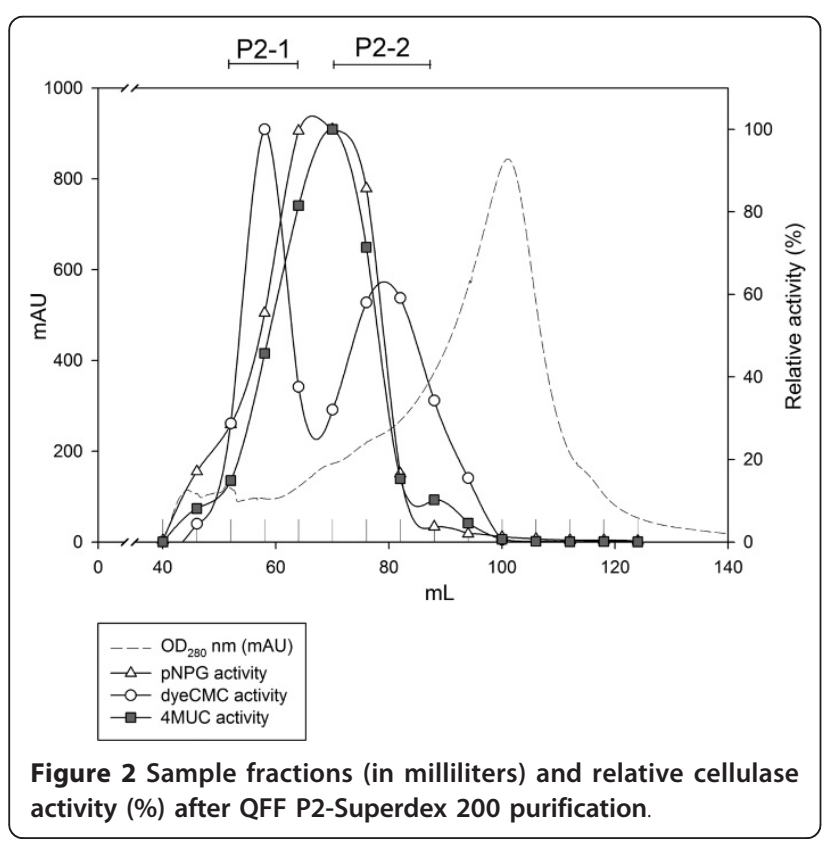

online protein sequences. The transcriptome data could alleviate such insufficiency.

\section{Transcriptomic analysis of $N$. patriciarum W5}

To induce the expression of as many kinds of proteins involved in biomass degradation as possible, we enriched the transcriptome by culturing the W5 strain separately in defined medium with different celluloses (CMC, avicel and cellobiose) and feedstocks (rice straw, napiergrass and sugarcane). To prepare a sample for transcriptome sequencing, equal amounts of total RNA from independent batch cultures were pooled together. The combined RNA sample was first converted into double-stranded cDNA, then fragmented by nebulization, made into a shotgun library and subjected to Roche 454 GS FLX sequencing.

A total of 526,516 raw reads were generated from sequencing of this transcriptome. Nucleotide content analysis indicated that $N$. patriciarum W5 has high AT content (63\%) (Table 2), which is consistent with its genome sequence (data not shown). To obtain the first draft of expressed sequences, the raw reads were assembled using Newbler version 1 software (454/ Roche), leading to the initial contig data set. Sequences longer than $500 \mathrm{bp}$ were selected for BLAST searches of the National Center for Biotechnology Information (NCBI) database and scored for the top hits with similarity to known cellulase genes. The candidates were then subjected to cDNA cloning. 


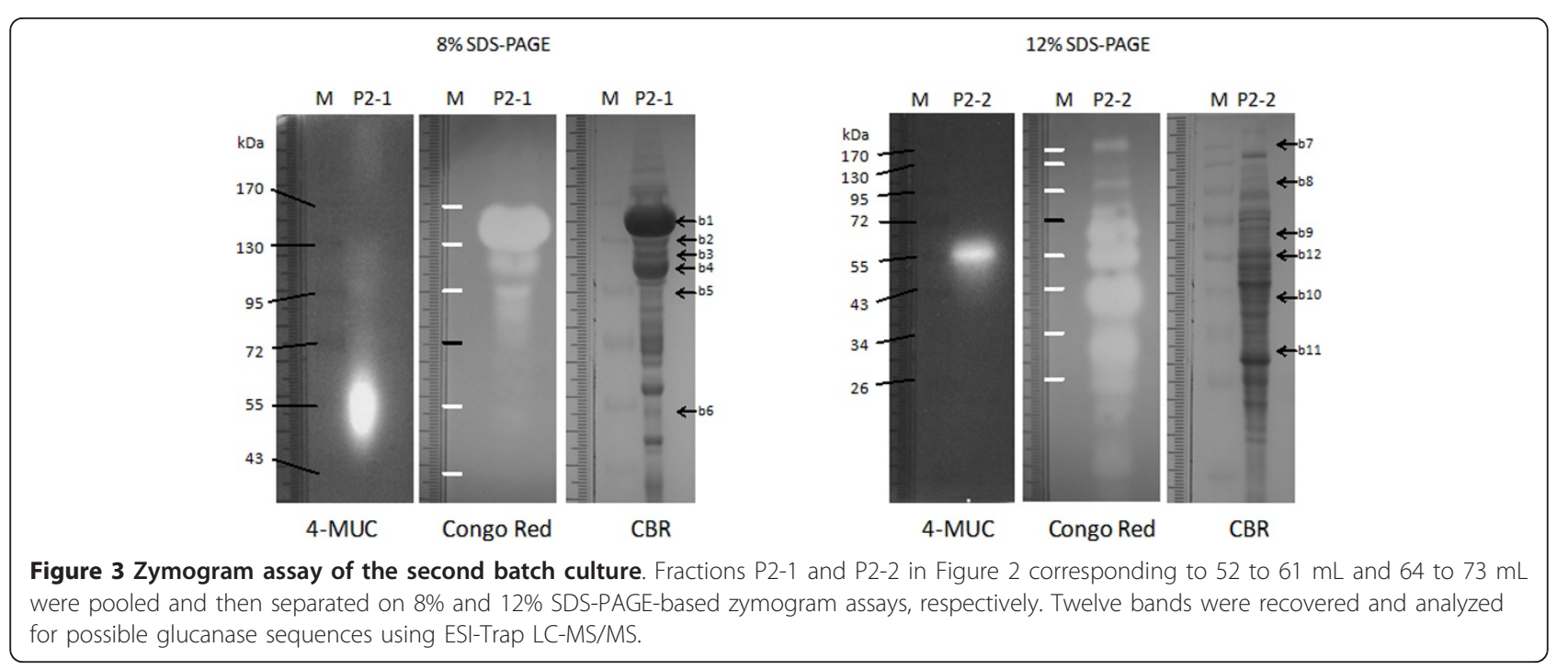

To obtain an EST data set with higher assembly accuracy, the 454 raw reads were first trimmed by the SeqClean program (http://compbio.dfci.harvard.edu/tgi/ software/) to remove poly(A/T) tails. The preprocessed reads were then assembled into 20,232 unique contigs using CAP3 software [31]. As shown in Figure 4, the

Table 2 Summary of transcriptome analyses ${ }^{a}$

\begin{tabular}{lc}
\hline Transcriptome analyses & W5 cDNA \\
\hline Roche 454 GS FLX & 1 \\
Run cycles & 526,516 \\
Total number of reads & 111 \\
Total read length, Mb & 210.2 \\
Average read length, bp & \\
Illumina GA II Paired-End & $40+40$ \\
Read length, bp & 1 \\
Run lanes & $14,802,234$ \\
Total number of reads & 1,184 \\
Total read length, Mb & $37.1 \%$ \\
GC content & \\
Contig assembly & 20,232 \\
Contig numbers & 9.0 \\
Total contig lengths, Mb & 447.2 \\
Average contig length, bp & 4,397 \\
Largest contig length, bp & \\
Gene prediction, length > 500 bp & 2,284 \\
Number of ORFs & 9,720 \\
Number of domains predicted in ORFs & 846.9 \\
Average ORF length, bp & $31,647.2$ \\
Maximum RPKM ${ }^{b}$ value & 219 \\
Number of GH-like contigs & \\
\hline
\end{tabular}

${ }^{\mathrm{a}} \mathrm{GC}$ : the nucleotide $\mathrm{G}+\mathrm{C} \%$; GH: glycosyl hydrolase; ORF: open reading frame; RPKM: Reads Per Kilobase of exon model per Million mapped reads. ${ }^{b}$ RPKM is a method for estimating relative expression levels of a transcriptome by normalizing short-read expressed tags from deep sequencing over ORF length and total reads (RPKM) [35]. resulting EST contigs were used for six-frame open reading frame (ORF) prediction by GETORF software [32]. A total of 2,284 ORFs greater than $500 \mathrm{bp}$ in length were selected and translated into protein sequences as an input for domain prediction and for a LC-MS/MS in-house database. Domain prediction was conducted by conducting a RPS-BLAST search against the NCBI Conserved Domain Database (CDD) using default parameters [33]. Contigs related to sugar metabolism and cellulose degradation were selected based on domain prediction results using keywords such as "gly," "GH" and "ase." The top-scoring NCBI sequences were collected, totaling 153 known annotations from the 288 unique $G H$-like contigs (497 ORFs), including cellulases, hemicellulases, lipases, chitinases and cellulosome dockerin proteins. Among those, 219 contigs could be further classified into 25 putative $G H$ families (Table 3 and Additional file 2). The top four largest classes (contig numbers $>20$ ) of putative $G H$ families were $G H 6$ (15\%), GH10 (9.5\%), GH5 (9.1\%) and GH43 (9.1\%). Based on the Carbohydrate-Active EnZymes (CAZy) database (http://www.cazy.org/), the GH6 family is mainly composed of EG (EC 3.2.1.4) and cellobiohydrolase (EC 3.2.1.91), whereas the GH5, GH10 and GH43 families are mainly composed of xylanases [34]. Interestingly, the cellulases induced by these feedstocks are more complex than our expectation, as revealed by their high diversity.

Our comparative fungi $G H$ family gene analysis showed that $N$. patriciarum W5 has a greater number of cellulases and hemicellulases than in the other fungi studied, 108 and 61, respectively (Table 3). T. reesei only has 34 cellulases and 8 hemicellulases, and Aspergillus niger has 45 cellulases and 29 hemicellulases. In the non-cellulose-degrading yeasts such as Kluyveromyces 


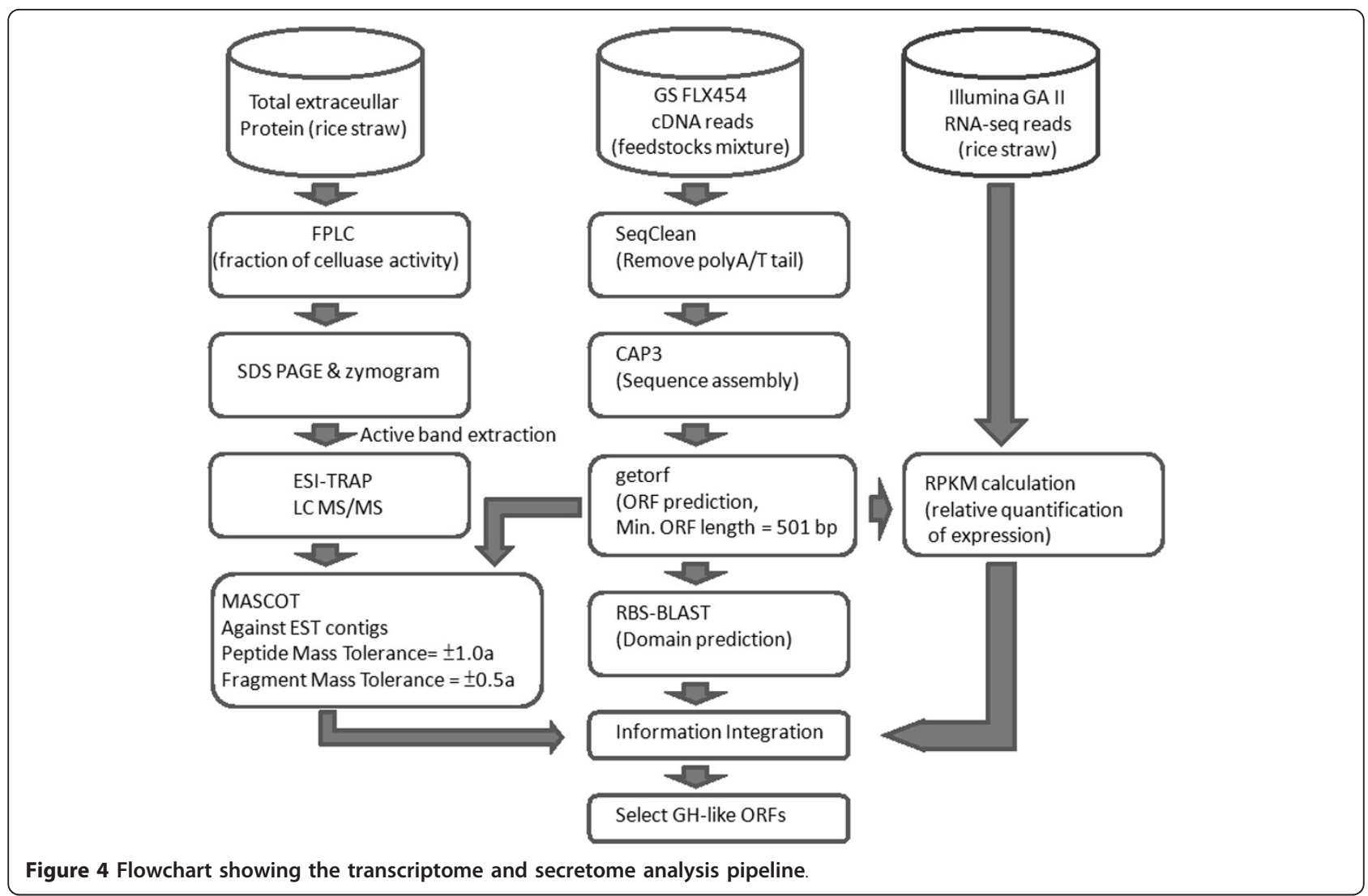

lactis and Yarrowia lipolytica, only a fraction of $\mathrm{GH} 3$ and GH5 family genes could be found in their genome sequences (data not shown). Our transcriptome analysis showed that $N$. patriciarum W5 utilized several common GH gene families, such as GH1, GH5, GH6, GH10, GH11 and GH43, and also specific gene families, such as $G H 9$ and $G H 48$, for degrading the cellulose of rice straw (Table 3). These observations suggest that a combination of several cellulases may be required to hydrolyze rice straw more efficiently. The diversity and specificity of $G H$ gene families could provide synthetic biologists with the opportunity to build up a yeast host with these major $G H$ genes for consolidated bioprocess (CBP) and/or coculture processing.

To investigate the quantitative gene expression in W5 cultured with rice straw, independent transcriptome sequencing was performed using the Illumina Genome Analyzer IIx for greater sequencing depth and throughput. A total of 14.8 million of the Illumina Genome Analyzer IIx paired-end reads (Table 2) were mapped to the EST contig data set assembled by CAP3 to calculate Reads Per Kilobase of exon model per Million mapped

Table 3 Expressed cellulase- and hemicellulose-degrading enzymes of Neocallimastix patriciarum arranged by GH family ${ }^{a}$

\begin{tabular}{|c|c|c|c|c|c|c|c|c|c|c|c|c|c|c|c|c|c|c|c|c|c|c|}
\hline \multirow[b]{2}{*}{ Putative GH family } & \multicolumn{10}{|c|}{ Cellulase } & \multicolumn{12}{|c|}{ Hemicellulase } \\
\hline & 1 & 3 & 5 & 6 & 7 & 9 & 12 & 45 & 48 & 61 & 10 & 11 & 26 & 29 & 43 & 51 & 53 & 54 & 62 & 67 & 74 & 95 \\
\hline Neocallimastix patriciarum W5 & 7 & 10 & $20^{\mathrm{b}}$ & $33^{b}$ & & $12^{\mathrm{b}}$ & & $14^{\mathrm{b}}$ & $12^{\mathrm{b}}$ & & $21^{\mathrm{b}}$ & $15^{\mathrm{b}}$ & $4^{b}$ & & $20^{b}$ & & 1 & & & & & \\
\hline Neurospora crassa OR74A & 1 & 9 & 7 & 3 & 5 & & 1 & 1 & & 14 & 4 & 2 & 1 & & 7 & 1 & 1 & $1^{\mathrm{b}}$ & & $1^{\mathrm{b}}$ & 1 & \\
\hline Magnaporthe grisea $70-15$ & 2 & 19 & 13 & 3 & $6^{b}$ & & 3 & 1 & & 17 & 5 & 5 & & $4^{b}$ & 19 & 3 & 1 & $1^{\mathrm{b}}$ & $3^{b}$ & $1^{\mathrm{b}}$ & 1 & 1 \\
\hline Aspergillus nidulans FGSC A4 & 3 & 20 & 15 & 2 & 3 & & 1 & 1 & & 9 & 3 & 2 & 3 & & 15 & 2 & 1 & $1^{\mathrm{b}}$ & 2 & $1^{\mathrm{b}}$ & $2^{b}$ & $3^{b}$ \\
\hline Aspergillus niger CBS 513.88 & 3 & 17 & 10 & 2 & 2 & & $4^{b}$ & & & 7 & 1 & 4 & 1 & 1 & 10 & $4^{\mathrm{b}}$ & $2^{b}$ & $1^{\mathrm{b}}$ & 1 & $1^{\mathrm{b}}$ & 1 & 2 \\
\hline Aspergillus oryzae RIB40 & 3 & $23^{b}$ & 14 & 1 & 3 & & $4^{b}$ & & & 8 & 4 & 4 & 1 & & $20^{\mathrm{b}}$ & 3 & 1 & $1^{\mathrm{b}}$ & 2 & $1^{\mathrm{b}}$ & & $3^{b}$ \\
\hline Leptosphaeria maculans v23.1.3 & 3 & 13 & 15 & 3 & 3 & & 3 & 2 & & $20^{\mathrm{b}}$ & 3 & 2 & 1 & 1 & 11 & 3 & 1 & & 1 & $1^{\mathrm{b}}$ & & 1 \\
\hline Trichoderma reeseic & 2 & 13 & 11 & 1 & 2 & & 2 & 1 & & 2 & 1 & 3 & & & 2 & & & & 1 & $1^{\mathrm{b}}$ & & \\
\hline
\end{tabular}

${ }^{a} G H$ : glycosyl hydrolase; CAZy: Carbohydrate-Active enZYmes database. ${ }^{\mathrm{b}}$ Highest gene number among fungi from JGI database and CAZy annotation. ${ }^{\mathrm{C}}$ Adapted from JGI database. 
reads (RPKM) for all contigs [35]. The quantification analyses (Tables 4 and 5) indicate the relative expression levels of the $G H$-like contigs identified in the secretome and those from sequencing and cloning, respectively.

Next, we investigated the expression of the major cellulases induced by rice straw according to RPKM value, which represented the normalized expression level from the transcriptome (see Additional file 2). Twenty-seven contigs showed a RPKM value $>500$, which were the major components of induced cellulases, including the GH1, GH3, GH4, GH6, GH10, GH11, GH38/GH57, GH43 and GH48 families. Among these, contig2828 (GH4, malate dehydrogenase), contig13654 (GH48, cellulase Cel48A), contig3216 (GH11, xylanase), contig9299 (GH6, cellobiohydrolase II-like cellulase) and contig20167 (GH6, cellobiohydrolase II-like cellulase) are the top five genes of highest expression. GH6 (eight contigs) and GH43 (six contigs) are the two most highly represented families among these twenty-eight contigs. In short, the major cellulosic genes induced by rice straw are cellulases (BGLU, cellobiohydrolase, cellobiohydrolase II-like cellulase and cellulase Cel48A) and hemicellulases (xylanase, $\beta$-xylosidase and endo-1,4- $\beta$ xylanase).

To reveal the function of cellulase genes, the secretome mass data were subjected to BLAST analysis against the transcriptome EST data set. As shown in Table 4, 40 of the 220 unique $G H$-like contigs were also hit multiple times by these peptide sequences. Specifically, BGLU, endo-1,4- $\beta$-xylanase, xylanase $B$ and Cel48A (GH48 family) constituted the major sequence annotations, among which the two xylanases of $N$. patriciarum were published [21,25]. The congruent results between the transcriptome and secretome analyses may imply that the enzymes mentioned above are the major protein constituents for degrading rice straw during processing. A good sequence database assembled from 454 data not only provides EST sequences for cDNA cloning but also helps to annotate the proteomic data more accurately than the previous online database (see Additional file 1). Taken together, both transcriptome and proteome analyses help one to explore the major functional enzymes involved in rice straw degradation. Such information may assist in the design of the CBP by combining the major cellulases in one microbe.

In addition to cellulases, our study also uncovered proteins associated with the cellulosome in rumen fungi, such as contig8798, which is annotated as a cellulosome enzyme dockerin type I protein, as well as many contigs that were predicted to contain the CBM10 domain (pfam02013). These conserved domains are responsible for assembly of multimeric cellulase/hemicellulase protein complexes and are the noncatalytic docking domains of cellulosomes found in anaerobic fungi
$[36,37]$. Our results suggest that a possible cellulosome complex exists in N. patriciarum for the adhesion and hydrolysis of lignocelluloses.

However, we could not detect a large amount of secreted cellulase activity in the medium, because the cellulases of N. patriciarum W5 may form a complex cellulosome structure and bind to the surface of the cellulose substrates. The fact that many cellulases and BGLUs from $N$. patriciarum W5 have a dockering domain (CBM10) suggests that there are cellulosomes in $N$. patriciarum W5 on which cellulases might be located. The concentration of extracellular cellulase proteins of $N$. patriciarum W5 detected in our laboratory was about 138.2 to $193.7 \mathrm{mg} / \mathrm{L}$, of which $30 \%$ showed xylanase activity.

\section{Validation and functional assay of potential novel cellulase genes}

On the basis of transcriptome and secretome analyses, 19 highly expressed (high RPKM values) or potentially full-length contigs were selected for cellulase gene cloning. This serves two purposes: to validate the assembly predictions and to obtain actual sequences for functional expression.

These putative cellulase genes were then introduced into Pichia pastoris or Saccharomyces cerevisiae for expression. Enzymatic screening of these constructs by 4-MUC activity assay indicated that several putative cellulases function normally in these yeast hosts, including genes with homology to $G H$ families $G H 1, G H 3$, GH5, GH6, GH9 and GH48 (Table 5). In addition, most of them carry the CBM10 domain, a cellulose binding module whose structure in solution has been resolved [38]. Significantly, some contigs assembled from the 454 data were almost identical to each other. Polymerase chain reaction (PCR) cloning using primer pairs from consensus regions among these contigs indeed led to identification of many respective sequences, suggesting the presence of transcript isoforms and/or gene families in the genome rather than sequencing or assembly errors. Taken together, these results show good sequence quality from the transcriptomic data and fast identification of desired genes by complementation of omics analyses.

Four potential novel, functional cellulase genes were chosen for further $p$ NPG and dye-CMC enzymatic assays (Table 5 and Figure 5). The cloned cellulase genes ranged between 1,989 and 2,361 bp long and had two or three predicted $N$-glycosylation sites. Two of them are putative BGLU genes, one of which belongs to the GH3 family (clone W5-16143) and the other of which belongs to the GH1 family (clone W5-CAT13). None of the BGLUs seems to have a cellulose binding domain. The exocellulase gene (clone W5-CAT26) 
Table 4 Forty unique $\mathrm{GH}$-like contig hits by BLAST analysis of secretome mass data against transcriptome assembly ${ }^{a}$

\begin{tabular}{|c|c|c|c|c|c|c|}
\hline $\begin{array}{l}\text { Contig } \\
\text { name }\end{array}$ & $\begin{array}{l}\text { Putative } G H \\
\text { family }\end{array}$ & $\begin{array}{l}\text { Gene } \\
\text { length }\end{array}$ & $\begin{array}{l}\mathrm{RPKM}^{\mathrm{b}} \\
\text { value }\end{array}$ & $\begin{array}{l}\text { Accession } \\
\text { number }\end{array}$ & $\begin{array}{l}\text { Enzyme annotation [species } \\
\text { name] }\end{array}$ & $\begin{array}{l}\text { Mass spot hits (a: first batch; b: second } \\
\text { batch; c: third batch) } \\
\text { (number: band ID on SDS-PAGE) }\end{array}$ \\
\hline Contig18827 & GH13 & 891 & 105.6 & EEQ33998.1 & $\begin{array}{l}\text { 1,4- } \alpha \text {-glucan branching enzyme } \\
\text { [Microsporum canis] }\end{array}$ & b9 \\
\hline Contig148 & GH13 & 819 & 19.8 & XP_963252.2 & $\begin{array}{l}\text { 1,4- } \alpha \text {-glucan branching enzyme } \\
\text { [Neurospora crassa] }\end{array}$ & b9 \\
\hline Contig1907 & GH1 & 882 & 757.2 & CAC34952. $1^{\mathrm{C}}$ & $\beta$-glucosidase [Piromyces sp. E2] & $a 3, a 10, b 4, b 5, b 6, b 8, b 9, b 12$ \\
\hline Contig11849 & GH3 & 2,064 & 29.0 & ZP_04746179.1 & $\beta$-glucosidase [Roseburia intestinalis] & b5 \\
\hline Contig4463 & GH1 & 522 & $2,290.4$ & AAP30745. ${ }^{c}$ & $\begin{array}{l}\beta \text {-glucosidase Cel1C [Piromyces sp. } \\
\text { E2] }\end{array}$ & a11, b2, b4, b5, b10, b12 \\
\hline Contig16557 & GH1 & 1,959 & $1,612.4$ & AAP30745. $1^{c}$ & $\begin{array}{l}\beta \text {-glucosidase Cel1C [Piromyces sp. } \\
\text { E2] }\end{array}$ & $a 3, a 10, a 11, b 1, b 2, b 4, b 5, b 8, b 9, b 10, b 12$ \\
\hline Contig7663 & GH1 & 1,959 & $1,096.6$ & AAP30745. ${ }^{c}$ & $\begin{array}{l}\beta \text {-glucosidase Cel1C [Piromyces sp. } \\
\text { E2] }\end{array}$ & $a 3, a 10, a 11, b 1, b 2, b 4, b 5, b 8, b 9, b 10, b 12$ \\
\hline Contig19120 & GH1 & 1,548 & 166.5 & AAP30745. ${ }^{c}$ & $\begin{array}{l}\beta \text {-glucosidase Cel1C [Piromyces sp. } \\
\text { E2] }\end{array}$ & b1, b2, b5, b6 \\
\hline Contig8008 & GH3 & 2,277 & 408.1 & $\mathrm{AAO} 41704.1^{\mathrm{c}}$ & $\begin{array}{l}\beta \text {-glucosidase precursor [Piromyces } \\
\text { sp. E2] }\end{array}$ & b2, b3, b4, b5, b6, b8, b12 \\
\hline Contig2687 & GH6 & 552 & 241.0 & AAR08200.1 & CelA [Neocallimastix frontalis] & a11 \\
\hline Contig6374 & GH6 & 1,854 & 24.7 & AAM94167.1 ${ }^{c}$ & $\begin{array}{l}\text { Cellulosomal exoglucanase Cel6A } \\
\text { [Piromyces equi] }\end{array}$ & b5 \\
\hline Contig12342 & GH43 & 1,653 & 664.5 & ZP_06201238.1 & $\begin{array}{l}\text { Conserved hypothetical protein } \\
\text { [Bacteroides sp. D20] }\end{array}$ & b12 \\
\hline Contig19148 & GH10 & 519 & 7.8 & YP_001181173.1 & $\begin{array}{l}\text { Endo-1,4- } \beta \text {-xylanase } \\
\text { [Caldicellulosiruptor saccharolyticus] }\end{array}$ & b4 \\
\hline Contig1253 & GH43 & 2,103 & 236.9 & ACZ98594.1 & $\begin{array}{l}\text { Endo-1,4- } \beta \text {-xylanase [Cellulosilyticum } \\
\text { ruminicola] }\end{array}$ & a11 \\
\hline Contig15284 & GH11 & 1,137 & 341.8 & ACL68347.1 & $\begin{array}{l}\text { Endo-1,4- } \beta \text {-xylanase [Neocallimastix } \\
\text { patriciarum] }\end{array}$ & b5 \\
\hline Contig8371 & GH11 & 2,412 & 158.3 & ACL68347.1 & $\begin{array}{l}\text { Endo-1,4- } \beta \text {-xylanase [Neocallimastix } \\
\text { patriciarum] }\end{array}$ & b3, b9 \\
\hline Contig19624 & GH45 & 696 & 60.0 & CAB92325.1 c & Endoglucanase 45A [Piromyces equi] & b3 \\
\hline Contig14117 & GH11 & 1,017 & 159.8 & CAA57820.1 & $\begin{array}{l}\text { Endoxylanase [Neocallimastix } \\
\text { frontalis] }\end{array}$ & b9 \\
\hline Contig18110 & GH11 & 879 & 32.3 & CAA57820.1 & $\begin{array}{l}\text { Endoxylanase [Neocallimastix } \\
\text { frontalis] }\end{array}$ & b9 \\
\hline Contig10964 & GH18 & 687 & 82.7 & YP_001643260.1 & $\begin{array}{l}\text { GH family protein [Bacillus } \\
\text { weihenstephanensis] }\end{array}$ & b4, b8 \\
\hline Contig6246 & GH31 & 1,932 & 232.1 & XP_002438844.1 & $\begin{array}{l}\text { Hypothetical protein [Sorghum } \\
\text { bicolor] }\end{array}$ & b2 \\
\hline Contig13446 & GH31 & 3,237 & 301.4 & XP_002109215.1 & $\begin{array}{l}\text { Hypothetical protein [Trichoplax } \\
\text { adhaerens] }\end{array}$ & a4 \\
\hline Contig2828 & $\mathrm{GH} 4$ & 948 & $9,936.5$ & CAA76361.1 & $\begin{array}{l}\text { Malate dehydrogenase [Piromyces } \\
\text { sp. E2] }\end{array}$ & b8 \\
\hline Contig9297 & GH1O & 993 & 984.7 & AAB30669.1 & $\begin{array}{l}\text { Xylanase B; XYLB [Neocallimastix } \\
\text { patriciarum] }\end{array}$ & b2, b3, b4, b5, b10 \\
\hline Contig13211 & GH1O & 819 & 352.0 & AAB30669.1 & $\begin{array}{l}\text { Xylanase } B ; X Y L B \text { [Neocallimastix } \\
\text { patriciarum] }\end{array}$ & b2, b3, b5 \\
\hline Contig13165 & GH1O & 990 & 205.1 & AAB30669.1 & $\begin{array}{l}\text { Xylanase } B ; \text { XYLB [Neocallimastix } \\
\text { patriciarum] }\end{array}$ & b3, b5, b10 \\
\hline Contig8421 & GH1O & 1,998 & 138.5 & AAB30669.1 & $\begin{array}{l}\text { Xylanase B; XYLB [Neocallimastix } \\
\text { patriciarum] }\end{array}$ & b9 \\
\hline Contig2430 & GH1O & 1,098 & 132.9 & AAB30669.1 & $\begin{array}{l}\text { Xylanase B; XYLB [Neocallimastix } \\
\text { patriciarum] }\end{array}$ & b10, b12 \\
\hline Contig3792 & GH1O & 927 & 5.1 & AAB30669.1 & $\begin{array}{l}\text { Xylanase B; XYLB [Neocallimastix } \\
\text { patriciarum] }\end{array}$ & a5 \\
\hline Contig11636 & GH43 & 510 & 966.2 & BAC75546.1 & Xylosidase [Penicillium herquei] & $a 1, c 11$ \\
\hline
\end{tabular}


Table 4 Forty unique $\mathrm{GH}$-like contig hits by BLAST analysis of secretome mass data against transcriptome assembly ${ }^{\mathrm{a}}$ (Continued)

\begin{tabular}{|c|c|c|c|c|c|c|}
\hline Contig8146 & GH1 & 1,986 & $2,290.4$ & AAD45834.1 ${ }^{c}$ & $\begin{array}{l}\beta \text {-glucosidase [Orpinomyces sp. PC- } \\
2 \text { ] }\end{array}$ & b2, b12 \\
\hline Contig13432 & GH1 & 723 & 33.0 & AAD45834.1 ${ }^{c}$ & $\begin{array}{l}\beta \text {-glucosidase [Orpinomyces sp. PC- } \\
2 \text { ] }\end{array}$ & $a 8, a 10, b 5, b 6$ \\
\hline Contig13654 & GH48 & 2,271 & $6,167.8$ & AAN76734.1 ${ }^{c}$ & $\begin{array}{l}\text { Cellulase Cel48A precursor } \\
\text { [Piromyces sp. E2] }\end{array}$ & $a 2, a 3, a 10, a 11, b 10, b 12$ \\
\hline Contig4845 & GH48 & 2,286 & 362.2 & AAN76734.1 ${ }^{c}$ & $\begin{array}{l}\text { Cellulase Cel48A precursor } \\
\text { [Piromyces sp. E2] }\end{array}$ & b10 \\
\hline Contig6576 & GH48 & 1,896 & 351.4 & AAN76734.1 ${ }^{c}$ & $\begin{array}{l}\text { Cellulase Cel48A precursor } \\
\text { [Piromyces sp. E2] }\end{array}$ & a11 \\
\hline Contig69 & GH48 & 1,179 & 141.9 & AAN76734.1 ${ }^{c}$ & $\begin{array}{l}\text { Cellulase Cel48A precursor } \\
\text { [Piromyces sp. E2] }\end{array}$ & $a 2, a 3, b 12$ \\
\hline Contig2523 & GH48 & 1,596 & 86.8 & AAN76735.1 ${ }^{c}$ & $\begin{array}{l}\text { Cellulase Cel48A precursor } \\
\text { [Piromyces equi] }\end{array}$ & $a 2, a 11, b 12$ \\
\hline Contig6878 & GH9 & 1,032 & 285.9 & AAM81967.1 & $\begin{array}{l}\text { Cellulase Cel9A precursor [Piromyces } \\
\text { sp. E2] }\end{array}$ & b9 \\
\hline Contig8960 & GH9 & 2,037 & 154.1 & AAM81967.1 & $\begin{array}{l}\text { Cellulase Cel9A precursor [Piromyces } \\
\text { sp. E2] }\end{array}$ & b9 \\
\hline Contig7007 & GH11 & 1,131 & 479.8 & Q12667 & Endo-1,4- $\beta$-xylanase A & $b 2, b 3, b 4, b 5$ \\
\hline
\end{tabular}

${ }^{\mathrm{a}} \mathrm{GH}$ : glycosyl hydrolase; RPKM: Reads Per Kilobase of exon model per million mapped reads. ${ }^{\mathrm{b}} \mathrm{RPKM}$ is a method for estimating relative expression levels of a transcriptome by normalizing short-read expressed tags from deep sequencing over ORF length and total reads (RPKM) [35]. 'Online protein sequences hits by using only ESI-Trap LC-MS/MS data against MASCOT online database.

belongs to the GH48 family and carries two CBMs at the $\mathrm{C}$ terminus. The endocellulase gene (clone W500992) belongs to the GH9 family and has three CBMs at the $\mathrm{C}$ terminus.

To screen for candidate clones and to determine the time window for optimal cellulase expression in P. pastoris, a time course of 4-MUC assays for culture supernatants was carried out at 24-hour periodicity for up to 5 days. We found that the maximum activities for all genes appeared 72 hours after induction. Although all cultures showed activities toward the 4-MUC substrate, the specific type of cellulase activity could be determined by the differential response to the other two substrates, dye-CMC and $p$ NPG. As shown in Figure 5, the supernatant and cell pellet from each culture were used to assay the activities. All the results are presented as relative activities compared to the positive control as described in Methods. Their relative specific activities were determined by comparison to the benchmark enzymes, $C b h \mathrm{I}$ and EgIII of T. reesei and BglI of $A$. niger, for EXG (4-MUC), EG (dye-CMC) and BGLU ( $p$ NPG), respectively.

In the assay for 4-MUC, the W5-CAT26 showed no activity in the cell pellets. In contrast, W5-00992 and W5-16143 showed very high activities (> 100\%) in the pellets, suggesting that a large portion of the expressed cellulase was trapped inside the cell. In the dye-CMC assay, only the W5-00992 pellet showed apparent EG activity (27.5\% relative to that of $E g I I I)$, while all other candidates displayed low activities in both supernatants and pellets ( $<20 \%$ of EgIII's specific activity). In the $p$ NPG assay for BGLU activity, W5-CAT13 showed appreciable activities (> 69\% of Bgll's specific activity) in the supernatant.

In summary, our results derived from the enzymatic assays and comparisons to the benchmarks are consistent with the protein functions predicted on the basis of their sequences. However, most of them showed a majority of the activities in the cell pellets, indicating that the native signal peptides of these cellulase genes could not be well recognized in P. pastoris. In the pursuit to find the best expression system, these genes were also introduced into E. coli, but most of the proteins appeared to be nonfunctional or showed low activity in this prokaryote (data not shown), possibly due to protein misfolding or improper posttranslational modifications. Parallel experiments using S. cerevisiae as the expression host were performed, but no activities were detected in the supernatants (Table 5), suggesting strong retention of these exogenous proteins inside the cells. Overall, $P$. pastoris was found to be a better host for expressing cellulase genes from W5, because the proteins were reasonably active and some of them were highly active in the supernatant. Future work is required to replace or modify the sequence of the signal peptide to enhance secretion and thus to increase extracellular activity.

Interestingly, a number of sequence variants were identified from cloning of W5-10151 using only one pair of PCR primers, among which at least four unique variants (W5-10151-39, W5-10151-38, W5-10151-5 and W5-10151-6) were found. To verify the sequence 
Table 5 Nineteen $\mathrm{GH}$ family genes selected for evaluation of contig assembly and for cellulase expression in yeasts ${ }^{\mathrm{a}}$

\begin{tabular}{|c|c|c|c|c|c|c|c|c|c|c|c|}
\hline \multirow{2}{*}{$\begin{array}{l}\text { Cloning } \\
\text { sequence } \\
\text { ID }\end{array}$} & \multirow[t]{2}{*}{ Contig ID } & \multirow[t]{2}{*}{$\begin{array}{l}\text { Contig } \\
\text { length }\end{array}$} & \multirow[t]{2}{*}{$\begin{array}{l}\text { ORF } \\
\text { length }\end{array}$} & \multirow[t]{2}{*}{$\begin{array}{c}G H \\
\text { family }\end{array}$} & \multirow[t]{2}{*}{$\begin{array}{c}\text { CBM } \\
\text { domain }\end{array}$} & \multirow[t]{2}{*}{$\begin{array}{c}\text { Signal } \\
\text { peptide }^{b}\end{array}$} & \multirow[t]{2}{*}{$\begin{array}{l}\text { RPKM } \\
\text { value }\end{array}$} & \multirow[t]{2}{*}{$\begin{array}{c}\text { ESI-Trap LC- } \\
\text { MS/MS }\end{array}$} & \multirow[t]{2}{*}{$\begin{array}{l}\text { Domain } \\
\text { prediction }\end{array}$} & \multicolumn{2}{|c|}{$\begin{array}{l}\text { Enzyme activity } \\
\text { assay }^{d}\end{array}$} \\
\hline & & & & & & & & & & $\begin{array}{c}P . \\
\text { pastoris }\end{array}$ & $\begin{array}{c}\text { S. } \\
\text { cerevisia }\end{array}$ \\
\hline W5-CAT13 & Contig8146 & 2,691 & 1,986 & GH1 & - & Y & $2,290.4$ & Y & $\beta$-glu & $\begin{array}{c}\beta-g l u(S, \\
P)^{\mathrm{e}}\end{array}$ & $\begin{array}{c}\text { No } \\
\text { activity }\end{array}$ \\
\hline W5-16143 & Contig4878 & 1,875 & 1,815 & $\mathrm{GH} 3$ & - & Y & 159.8 & Y & $\beta$-glu & $\underset{P)^{\mathrm{e}}}{\beta-g l u}(S$, & $\beta-g \operatorname{flu}_{f}(P)$ \\
\hline W5-celD ${ }^{9}$ & AF053363 & 3,949 & 1,383 & GH5 & CBM 10 & Y & - & Y & $E G+X y l$ & $E G \underset{f}{(S, P)}$ & NA \\
\hline W5C-P & Contig12293 & 1,392 & 1,392 & GH5 & CBM 10 & $\mathrm{~N}$ & 405.7 & & EG & NA & NA \\
\hline W5-CAT5 & Contig8755 & 1,582 & 1,479 & GH6 & CBM 10 & Y & $2,735.9$ & & EXG & $\begin{array}{l}\text { No } \\
\text { activity }\end{array}$ & $\begin{array}{l}\text { No } \\
\text { activity }\end{array}$ \\
\hline $\begin{array}{l}\text { W5-CAT6- } \\
9\end{array}$ & Contig8363 & 1,540 & 1,497 & GH6 & CBM 10 & Y & 203.2 & & EXG & $\begin{array}{c}\text { EXG }(S, \\
P)^{f}\end{array}$ & EXG $(P)^{f}$ \\
\hline W5-20147 & Contig20147 & 1,981 & 1,503 & GH6 & CBM 10 & Y & $3,576.0$ & & EXG & $\begin{array}{l}\text { No } \\
\text { activity }\end{array}$ & $\begin{array}{l}\text { No } \\
\text { activity }\end{array}$ \\
\hline W5C-O & Contig19058 & 1,449 & 1,197 & GH6 & CBM 1 & Y & $1,712.7$ & & EXG & NA & NA \\
\hline W5-16271 & Contig18112 & 1,754 & 1,389 & GH6 & CBM 10 & Y & 760.1 & & $E G+E X G$ & $\begin{array}{c}\text { No } \\
\text { activity }\end{array}$ & $\begin{array}{c}\text { No } \\
\text { activity }\end{array}$ \\
\hline W5-01055 & Contig13874 & 3,935 & 3,858 & GH6 & CBM 10 & $\mathrm{~N}$ & 239.8 & & EXG & $\begin{array}{l}\text { No } \\
\text { activity }\end{array}$ & $\begin{array}{l}\text { No } \\
\text { activity }\end{array}$ \\
\hline $\begin{array}{l}\text { W5-10151- } \\
39\end{array}$ & Contig9299 & 1,900 & 1,473 & GH6 & CBM 10 & Y & $4,397.8$ & & EXG & $\begin{array}{c}\text { EXG }(S, \\
P)^{f}\end{array}$ & EXG $(P)^{f}$ \\
\hline $\begin{array}{l}\text { W5-10151- } \\
38\end{array}$ & Contig9839 & 1,415 & 1,341 & GH6 & CBM 10 & Y & 414.1 & & EXG & $\begin{array}{c}\text { EXG }(S, \\
P)^{f}\end{array}$ & NA \\
\hline $\begin{array}{l}\text { W5-10151- } \\
5\end{array}$ & Contig15588 & 1,777 & 1,461 & GH6 & CBM 10 & Y & $2,727.9$ & & EXG & $\begin{array}{c}\text { EXG }(S, \\
P)^{f}\end{array}$ & NA \\
\hline $\begin{array}{l}\text { W5-10151- } \\
6\end{array}$ & Contig10151 & 1,852 & 1,494 & GH6 & CBM 10 & Y & 654.6 & & EXG & $\begin{array}{c}\text { EXG }(S, \\
P)^{f}\end{array}$ & NA \\
\hline W5-00992 & Contig8960 & 2,042 & 2,037 & GH9 & CBM 10 & Y & 154.1 & Y & EG & $\underset{e}{E G} \underset{(S, P)}{(S)}$ & $E G(P)^{f}$ \\
\hline W5-14806 & Contig10733 & 2,509 & 2,355 & GH9 & CBM 10 & Y & 165.6 & & EG & $\begin{array}{l}\text { No } \\
\text { activity }\end{array}$ & $\begin{array}{l}\text { No } \\
\text { activity }\end{array}$ \\
\hline W5-CAT24 & Contig4514 & 1,575 & 1,116 & GH18 & CBM 10 & $\mathrm{~N}$ & 88.1 & Y & Chitinase & NA & NA \\
\hline W5-CAT7 & Contig19103 & 2,619 & 2,262 & $\mathrm{GH} 43$ & $\begin{array}{l}\text { CBM 6, } \\
\text { CBM } 10\end{array}$ & $N$ & 747.4 & Y & Xyl & $\begin{array}{l}\text { No } \\
\text { activity }\end{array}$ & NA \\
\hline $\begin{array}{l}\text { W5- } \\
\text { CAT26-68 }\end{array}$ & Contig13654 & 2,793 & 2,271 & GH48 & CBM 10 & Y & $6,953.9$ & Y & EXG & $\begin{array}{c}\text { EXG }(S, \\
P)^{e^{e}}\end{array}$ & EXG $(P)^{f}$ \\
\hline
\end{tabular}

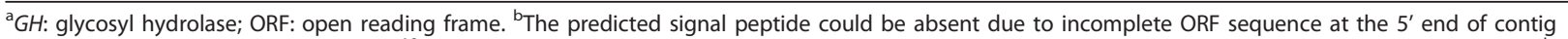
sequence. ' ${ }^{\top}$ Top score and e-value $<10^{-10}$ as putative domain: endoglucanase (EG), exoglucanase (EXG), $\beta$-glucanase ( $\beta$-glu), xylanase (Xyl) and chitinase. ${ }^{d_{4}}$ methylumbelliferyl- $\beta$-cellobiose (4-MUC) assays were used for broad cellulase activity analysis of endo-, exo-, $\beta$-glucanase and xylanase. $S=$ supernatant; $P=$ cell pellet. ${ }^{e}$ These cellulase constructs were chosen for subsequent enzymatic assays of dye CM-cellulose and $p$-nitrophenyl- $\beta$-D-glucopyranoside for their high 4-MUC activity expressed in P. pastoris (Figure 5). ${ }^{f}$ Low or undetectable levels of dye-CMC and $p$ NPG activity. ${ }^{9}$ celD is a known gene from National Center for Biotechnology Information GenBank (Xue et al. [26]). The cloned sequences were submitted to GenBank (GenBank:JF906702-GenBank:JF906719).

accuracy, the clones were checked by conducting a BLAST search against the 454 transcriptional contigs, and the cloning variants could be found in our contig data set (Table 5). Significantly, the one with the longest predicted ORF (W5-10151-39) displayed EXG activity when expressed in both yeast hosts.

\section{Conclusions}

This study successfully verified 19 potential cellulase genes out of 219 putative $G H$ family contigs using omics analyses, and 10 of them had detectable cellulase activity. By complementary application of the omics data, we identified four novel major cellulases from $N$. patriciarum W5 and expressed them in P. pastoris for functional expression. Characterizations of their cellulase activities imply that their enzymatic properties are competitive enough for potential commercialization.

Our transcriptomic data show high expression levels of the four cellulases in W5, and this was also supported by secretome analysis. In summary, this study showed that the secretome can be used to find major protein regions and that transcriptome analysis can predict full- 


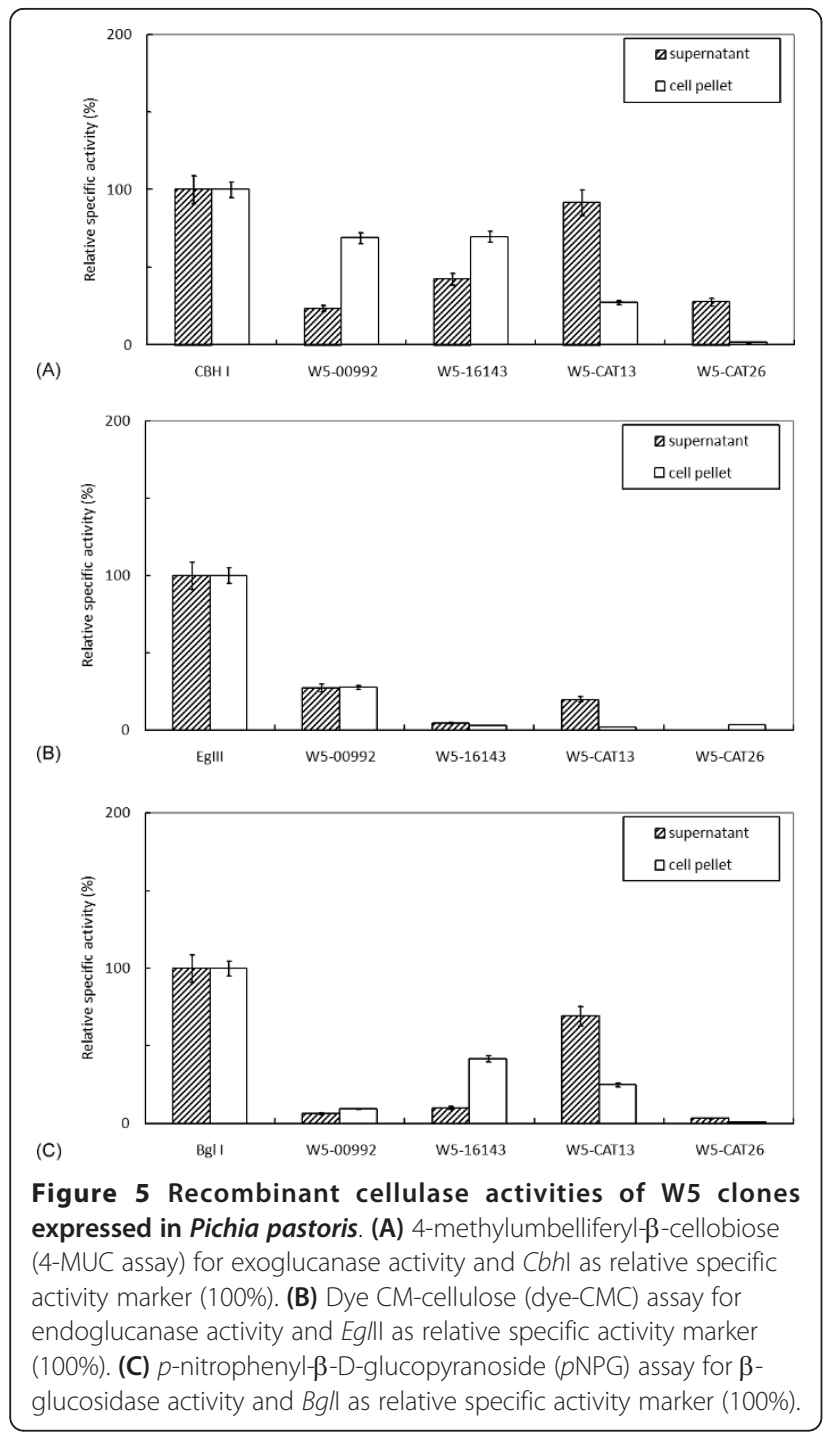

length gene assembly and provide insights into feedstock metabolism. Thus, omics approaches can be combined to accelerate novel gene discovery and functional gene selection in a comprehensive manner, especially for organisms with little sequence information.

\section{Methods}

\section{Microbial growth}

The growth condition of $N$. patriciarum W5 was adapted from a rumen content of a water buffalo. The isolate was maintained in a rumen fluid-containing medium supplemented with $0.5 \%$ rice straw as the sole carbon and was anaerobically grown at $39^{\circ} \mathrm{C}$ for three or four days [19] with some variations. Glucose, carboxylmethyl cellulose $(\mathrm{CMC})$, avicel or the powder of rice straw, napiergrass or sugarcane bagasse added to the broth $(300 \mathrm{~mL})$ as a sole carbon source to induce the cellulase production of $N$. patriciarum W5. To collect extracellular proteins from W5, four replicates of 300 $\mathrm{mL}$ of medium were cultured anaerobically in $39^{\circ} \mathrm{C}$ incubators for three to four days, and supernatants were harvested by centrifugation.

\section{Extracellular cellulase purification}

A total of $1.5 \mathrm{~L}$ of culture supernatants were filtered through a 0.2-mm membrane (Sartorius, Goettingen, Germany), then dialyzed and condensed 100-fold using Viva Flow 50 (10$\mathrm{kDa}$ cutoff) (Sartorius) against starting buffer $(50 \mathrm{mM}$ Tris. $\mathrm{HCl}, \mathrm{pH} 7.0$ ) to a final volume of $20 \mathrm{~mL}$ at $4^{\circ} \mathrm{C}$.

To purify the protein fractions that contain cellulases, sequential FPLC (ÄKTAFPLC; GE Healthcare, Taipei, Taiwan) was conducted. First, the samples were subjected to a HiPrep 16/10 QFF anion exchange column (GE Healthcare, Taipei, Taiwan) preequilibrated with $60 \mathrm{~mL}$ of starting buffer to stabilize the UV signal, and then a 10 - $\mathrm{mL}$ sample was applied and eluted for $60 \mathrm{~mL}$ with a step gradient using a $15 \%$ mixing ratio of elution buffer (50 mM Tris. $\mathrm{HCl}, 2 \mathrm{M} \mathrm{NaCl}, \mathrm{pH} 7.0$ ) at a constant flow of $3 \mathrm{~mL} /$ minute. Fractions of $5 \mathrm{~mL}$ from the eluates were collected and assayed for the activity of $p$ NPG, dye-CMC and 4-MUC (Sigma-Aldrich, St Louis, MO, USA), respectively. Fractions with apparent activity were pooled, condensed and dialyzed against gel filtration buffer $(20 \mathrm{mM}$ Tris. $\mathrm{HCl}, 150 \mathrm{mM} \mathrm{NaCl}, \mathrm{pH} 7.0)$ with Viva Spin (10-kDa cutoff). Four milliliters of the condensed sample were applied to the HiLoad 16/60 Superdex 200 gel filtration column (GE Healthcare, Taipei, Taiwan) with a constant flow of $1.2 \mathrm{~mL} / \mathrm{minute}$. All 3-mL fractions were assayed for enzyme activity using $p$ NPG, dye-CMC and 4-MUC as substrates. Fractions displaying the activity of BGLUs with EXGs ( $p$ NPG and 4-MUC) and EGs (dye-CMC) were pooled and condensed, respectively.

\section{Enzyme activity assay}

4-MUC assays were carried out for broad quantitative analysis of cellulase activity, and the activity was measured by fluorometry with excitation and emission wavelengths at 365 and $450 \mathrm{~nm}$, respectively. Dye-CMC was used as a substrate for the quantification of EG activity, and the activity was measured at $590 \mathrm{~nm}$. $p$ NPG was used as the substrate for assays of BGLU activity, and the activity was measured at $410 \mathrm{~nm}$. If both dye-CMC and $p$ NPG activity was low, the 4-MUC activity represented the exocellulase activity. Protein concentration was measured with the Protein Assay reagent (500-0006; Bio-Rad Laboratories, Hercules, CA, USA). The specific activities were defined as digesting $1 \mu \mathrm{M}$ substrate per milligram of protein per hour.

\section{SDS-PAGE}

SDS-PAGE was performed to examine the approximate protein sizes [39]. Proteins were separated on $12 \%$ 
polyacrylamide gels and stained with Coomassie Brilliant Blue R-250 (Bio-Rad Laboratories). The molecular weight markers were obtained from Fermentas (Burlington, ON, Canada).

\section{Zymogram assay}

A total of $100 \mu \mathrm{g}$ of pooled fractionated P2-1 and P2-2 were separated with $17 \times 17 \mathrm{~cm}$ of $12 \%$ SDS-PAGE controlled by the PROTEAN II xi electrophoresis system (Bio-Rad Laboratories). Duplicated samples were separated on the same $12 \%$ SDS-PAGE gel using non- $\beta$-ME sampling buffer and premixed without heating for zymogram tests. SDS-PAGE for the zymogram test was laid onto a 16-cm diameter of 1\% CMC (for EG; Calbiochem, Darmstadt, Germany); catalog no. 217277; Merck \& Co., Whitehouse Station, NJ, USA) agar plate prespread with $500 \mu \mathrm{L}$ of $2 \% 4$-MUC (for EXG), air-dried and finally moisturized with $0.5 \mathrm{~mL}$ of $90 \mathrm{mM}$ sodium acetate on top of the PAGE gel and kept at $30^{\circ} \mathrm{C}$ for three hours or overnight to detect the EXG or EG activity, respectively. The 4-MUC plate was measured by fluorometry under UV light at $365 \mathrm{~nm}$ for qualitative activity. The CMC plate was later stained with $15 \mathrm{~mL}$ of Congo Red $(1 \mathrm{mg} / \mathrm{mL})$ at room temperature for $40 \mathrm{~min}$ utes and then destained with $1 \mathrm{M} \mathrm{NaCl}$ to visualize reactive (transparent) bands. The transparent bands on the zymogram were estimated for size guided by molecular weight markers, and the corresponding bands on SDS-PAGE were sliced from the same size range, dissolved and digested with trypsin solution, and subjected to ESI-TRAP LC-MS/MS analysis.

\section{In-gel trypsin digestion}

The protocol used for in-gel trypsin digestion of proteins in gels was adapted mainly from a method described previously [40]. Briefly, the protein bands from one-dimensional gel were excised, and each band was diced into small pieces (about $0.5 \mathrm{~mm}^{3}$ ). The gel pieces were placed into microfuge tubes and washed a few times with solution containing 50\% methanol and $5 \%$ acetic acid for two to three hours, followed by two washes with a solution of $25 \mathrm{mM} \mathrm{NH} \mathrm{NCO}_{3}$ in $50 \%$ acetonitril for 10 minutes each, and then the gel pieces were dried in a vacuum centrifuge. Reduction with dithiothreitol (DTT) and alkylation with iodoacetamide of proteins in gel pieces were performed, and the gel pieces were washed and dried in a vacuum centrifuge before trypsin digestion. A $25-$ to $40-\mu \mathrm{L}$ trypsin solution in $25 \mathrm{mM} \mathrm{NH}_{4} \mathrm{HCO}_{3}$ containing 75 to $100 \mathrm{ng}$ of sequencing grade modified trypsin (Promega, Madison, WI, USA) was added and incubated with gel pieces for 12 to 16 hours at $37^{\circ} \mathrm{C}$. To recover the tryptic peptides, a solution of $30 \mu \mathrm{L}$ containing $5 \%$ formic acid and $50 \%$ acetonitril was added to the gel pieces, agitated in a vortex for 30 to 60 minutes and transferred into a new tube. The remains were repeated once with $15 \mu \mathrm{L}$ of solution, and the resulting two eluates were combined and dried in a vacuum centrifuge. The dried pellet was redissolved in 10 to $20 \mu \mathrm{L}$ of $0.1 \%$ formic acid for $\mathrm{LC}$ MS/MS analysis (Proteomics Core Laboratory, IPMB, Academia Sinica, Taipei, Taiwan).

\section{MS method for protein identification and analysis}

An LTQ mass spectrometer model coupled with an online capillary LC system from Thermo Fisher Scientific (Waltham, MA, USA) was utilized for protein identification and analysis. The capillary LC system equipped with an autosampler and Surveyor pumps (Thermo Fisher Scientific), a C18 trap column $(100 \mu \mathrm{m} \times 3.0 \mathrm{~cm}, 5 \mu \mathrm{m}$, 200-Å Magic C18 AQ resin; Michrom Bioresources, Inc., Auburn, CA) and a C18 reverse phase column $(75 \mu \mathrm{m} \times$ $11 \mathrm{~cm}, 5 \mu \mathrm{m}, 100$ - $\AA$ Magic C18 resin, Auburn, CA) was used to deliver solvent and to separate tryptic peptides with a linear gradient from $5 \%$ to $40 \%$ of acetonitril in $0.1 \%$ (vol/vol) formic acid for 40 minutes (or 60 minutes) at the nanoflow rate of approximately $300 \mathrm{~nL} /$ minute. A sample volume of $5 \mu \mathrm{L}$ was loaded onto the column. The C18 reverse phase column was coupled to a nanoelectrospray ionization source, and the acquisition of the data was conducted with a full MS scan followed by four MS/MS scans of the top four precursor ions from the MS scan. The MS scan was conducted over the mass-tocharge $(\mathrm{m} / z)$ range 400 to 1,800 using the data-dependent data acquisition mode with dynamic exclusion enabled. The acquired ESI-TRAP MS/MS data were analyzed using a MASCOT MS/MS Ion Search program (http://www.matrixscience.com/) against the ORFs of our transcriptome database. The peak list data (DTA) used for the database search were generated from MS/MS spectra using an ion intensity threshold of 1,000 and a minimum ion count of 10 . The protein sequences in the database were indexed with trypsin digestion with two missed cleavages, the 600 to 3,500 molecular weight range, a variable modification of Met by oxidation and a static modification of Cys by carboxyamidomethylation. The DTA data were searched with 1.0 atomic mass units (u) of precursor peptide mass tolerance and $0.5 \mathrm{u}$ of fragment mass tolerance. The matched peptides were accepted when they passed multiple filters, $X_{\text {corr }} \geq 1.5$ for singly charged ions $(z=1), X_{\text {corr }} \geq 2.0$ for doubly charged ions $(z=2), X_{\text {corr }} \geq 2.5$ for triply charged ions $(z=3)$, $\Delta \mathrm{CN} \geq 0.1$ and peptide probability $\leq 1 \times 10^{-3}$. Matched proteins were accepted only when they had at least two distinct peptide hits.

\section{RNA extraction and CDNA synthesis of W5}

The cells were cultured under anaerobic conditions at $39^{\circ} \mathrm{C}$ for 2.5 days, and then the medium was removed 
by filtration to collect the cells. The culture mass was ground in liquid nitrogen, and total RNA was extracted using the hot acid phenol-chloroform method and quantified on a spectrophotometer. From each substrateinduced culture $(\mathrm{CMC}$, avicel, cellobiose, rice straw, sugarcane and napiergrass), equal amounts of total RNA were pooled together. The mRNA of the pooled cellulose-induced total RNA samples were enriched using the Dynabeads mRNA Purification Kit (Invitrogen, Carlsbad, CA, USA), and double-stranded cDNA was synthesized from the $10 \mu \mathrm{g}$ of purified mRNA sample using the SuperScript Double-Stranded cDNA Synthesis Kit (Invitrogen) according to the manufacturer's instructions. The cDNA were then fragmented and prepared for the shotgun libraries according to Roche's protocols. The deep sequencing experiments were carried out on the GS FLX Sequencer by Mission Biotech Co., Ltd. (Taipei, Taiwan).

To synthesize the rice straw-induced cellulase containing cDNA for reverse transcriptase (RT)-PCR and gene cloning, reverse transcription using total RNA was carried out with the SuperScript ${ }^{\mathrm{TM}}$ II Reverse Transcriptase Kit (Invitrogen). The reaction contained the total RNA $(4 \mu \mathrm{g})$, oligo $(\mathrm{dT})$ primer, BD SMART II A oligo (Clontech, Mountain View, CA, USA), $4 \mu \mathrm{L}$ of $5 \times$ RT buffer, $10 \mathrm{mM}$ DTT, $0.5 \mathrm{mM}$ each of deoxyribonucleotide triphosphate and $10 \mathrm{U}$ of SUPERSCRIPTTM II RNase H Reverse Transcriptase (Invitrogen). The single-stranded DNA product was stored at $-20^{\circ} \mathrm{C}$.

\section{Transcriptome analysis: cDNA assembly, ORF prediction and domain prediction}

The 454 sequence reads were processed through SeqClean to remove poly( $\mathrm{T})$ stretches and then assembled into unique contigs by CAP3 (read minimum overlap length $=40$ with minimum identity $=0.9$ ). ORFs were predicted by GETORF, a part of EMBOSS software [32], for in-frame regions between a start and a stop codon. All predicted ORFs were then submitted to local RPSBLAST [33] and the NCBI CDD database to retrieve domain predictions with an e-value $<10^{-5}$.

For quantitative profiling, an RNA-Seq library was constructed from the cDNA (synthesized from rice straw-induced RNA) using the Illumina kit, and pairedend sequencing was performed on the Illumina GA2 sequencer of the High Throughput Sequencing Core at Academia Sinica, Taipei, Taiwan. Reads from PE2*40 nucleotides ( 7.4 million pairs) (insert range between 180 and $220 \mathrm{bp}$ ) were obtained. The data were mapped to the EST contigs derived from 454 assembly and PCR cloning, and the relative expression levels were calculated by the RPKM method [35] using CLC-bio Genomics Workbench software (CLC bio, Aarhus N, Denmark) and sorted by ranking. The contigs with
ORFs longer than $500 \mathrm{bp}$ were further analyzed for $G H$ family gene classification. The sequences with the highest RPKM scores and significant e-values $\left(<10^{-10}\right)$ were selected for functional annotation. The analysis flowchart is illustrated in Figure 4.

\section{Strains and plasmids used for cloning and expression}

The E. coli DH5 $\alpha$ strain was used as a host for cloning and plasmid propagation. The strain was cultured in a low-salt LB medium. P. pastoris GS115 strain (Invitrogen) was used as a host for expressing cloned cellulase genes. The $P$. pastoris transformants were selected in YPD (1\% yeast extract, $2 \%$ peptone, $2 \%$ dextrose) plates containing $100 \mu \mathrm{g} / \mathrm{ml}$ of zeocin. For expression, the BMGY medium and the BMMY medium were used and prepared according to the Pichia expression system manual (Invitrogen). The $S$. cerevisiae transformants were selected in SC-URA plates. The pGEM-T easy vector (Promega) was used for gene cloning and sequencing. pPICZ A plasmid (Invitrogen) and pRS426 plasmid with glyceraldehyde 3-phosphate dehydrogenase (GAPDH) promoter were used for protein expression in $P$. pastoris and S. cerevisiae, respectively.

\section{Cloning and construction for selected cellulase genes}

The reverse-transcribed W5 cDNA was used to clone the selected cellulase genes by PCR using the gene-specific oligonucleotide primers the sequences of which were derived from the transcriptome contigs (Table 5). For each pair, the forward primer was engineered with XhoI (New England Biolabs, Ipswich, Massachusetts, USA) and the reverse primer was engineered with EcoRI (New England Biolabs) recognition sequences to allow for directional cloning into expression vector. After amplification, each PCR was cloned into the pGEM-T easy vector for sequencing. Plasmid DNA from the positive clones were digested by XhoI and EcoRI, and the putative cellulase gene was subcloned into the pPICZ A vector, which contained an AOX1 promoter that can be induced by methanol, and allowed for selection by the antibiotic zeocin. For expression in S. cerevisiae, the ORF of the candidate cellulase gene was fused with the GAPDH promoter and cloned into the pRS426 plasmid and then transformed into yeast cells. The procedures for plasmid preparation, restriction digestion, ligation and $E$. coli transformation were carried out in accordance with the manufacturers' protocols.

\section{Transformation and cellulase expression in Pichia pastoris} For growing $P$. pastoris GS115 cells, all cultures were incubated at $30^{\circ} \mathrm{C}$ with 250 -rpm orbital shaking. Procedures for preparation of competent cells were carried out according to the manufacturer's description (BioRad Laboratories). For transformation, $10 \mu \mathrm{g}$ of each 
cellulase construct in the pPICZ A vector was linearized with SacI (New England Biolabs) and transformed into yeast $P$. pastoris GS115 strain by the Gene Pulser Xcell (Bio-Rad Laboratories). The 200- $\mu \mathrm{L}$ electroporated mixtures were plated into YPD medium containing $100 \mu \mathrm{g} /$ $\mathrm{mL}$ zeocin and incubated at $30^{\circ} \mathrm{C}$ until colonies appeared. The introduction of each cellulase gene into the yeast cell was further confirmed by PCR using the forward and reverse primers of AOX1 promoter (Invitrogen). For expression and induction of the cellulase genes, the protocols were performed according to the Pichia expression system manual (Invitrogen). To monitor the activities of expressed proteins, 1-mL samples from culture were collected every 24 hours. After 1-mL samples were taken, methanol (100\%) was added to a final concentration of $0.5 \%$ ( $\mathrm{vol} / \mathrm{vol})$ to maintain induction. To screen for the Pichia transformants expressing high activity of cellulase protein, ten colonies were randomly selected from YPD/zeocin plates and individually cultured in $10 \mathrm{~mL}$ of $\mathrm{BMMY}$ at $30^{\circ} \mathrm{C}$ for five days for methanol induction.

\section{Transformation and cellulase expression in Saccharomyces cerevisiae}

Yeast BY4741 (MATa his $3 \Delta 1$ leu $2 \Delta 0$ met15 $\Delta 0$ ura3 $\Delta 0$ ), a descendant of $\mathrm{S} 288 \mathrm{C}$, was grown overnight at $30^{\circ} \mathrm{C}$ with 250-rpm shaking. Procedures for the preparation of competent cells were carried out according to the manufacturer's description (Bio-Rad Laboratories). For transformation, $200 \mathrm{ng}$ of each cellulase construct in pRS426 was directly transformed into yeast BY4741 strain using the Gene Pulser Xcell Electroporation System (Bio-Rad Laboratories). The 50- $\mu \mathrm{L}$ electroporated mixtures were incubated in $1 \mathrm{~mL}$ of YPAD (1\% yeast extract, $2 \%$ peptone, $0.04 \%$ adenine sulfate, $2 \%$ dextrose) and recovered after three hours of incubation at $30^{\circ} \mathrm{C}$ with $250-\mathrm{rpm}$ shaking. The transformants, after being centrifuged and washed twice with $1 \mathrm{~mL}$ of deionized distilled water, were selected on the SC-URA plate at $30^{\circ} \mathrm{C}$ until $\mathrm{URA}^{+}$ colonies appeared. Only the strains that carried the desired plasmids will survive and form colonies on the SC-URA plate. Ten colonies of transformants from each strain were randomly selected and cultured in $5 \mathrm{~mL}$ of SC-URA medium at $30^{\circ} \mathrm{C}$ for 24 hours, and the harvested supernatants were then screened by the 4-MUC activity. At least three higher-expression colonies of each gene were diluted to $600-\mathrm{nm}$ optical density $\left(\mathrm{OD}_{600}\right)=0.1$ and grown in $50 \mathrm{~mL}$ of SC-URA medium at $30^{\circ} \mathrm{C}$ for 24 hours. The condensed supernatants and collected cell pellets were assayed again.

\section{Functional screening and activity assay}

For the 4-MUC enzymatic assay, $40 \mu \mathrm{L}$ of the supernatants from the 1-mL sample (collected as described above) were added to reaction buffer (90 mM NaOAc, $\mathrm{pH}$ 5) containing $2 \mathrm{mg} / \mathrm{mL}$ 4-MUC (Sigma-Aldrich) and incubated for 20 hours at $30^{\circ} \mathrm{C}$ before addition of stop solution $\left(2 \% \mathrm{Na}_{2} \mathrm{CO}_{3}, \mathrm{pH} 11\right)$. The activity was determined by measuring absorbance at $\mathrm{OD}_{450} \mathrm{~nm}$ (excitation at $365 \mathrm{~nm}$ ) using the SpectraMax M2 Microplate Reader (Molecular Devices, Sunnyvale, CA, USA).

To find the best candidates from the ten transformants, 4-MUC assays were repeated to select three colonies that displayed the highest activity for each specific gene. The culture condition was the same as above, except for scaling up culture to $50 \mathrm{~mL}$ of BMMY.

To evaluate the activities of the cell pellet, the protein extraction procedure was based on the Pichia expression system manual (Invitrogen). For the 4-MUC enzymatic assay, $40 \mu \mathrm{L}$ of the pellet extractions from the $1-\mathrm{mL}$ culture harvest were added to reaction buffer $(90 \mathrm{mM}$ NaOAc, pH 5) containing 4-MUC at $2 \mathrm{mg} / \mathrm{mL}$ and incubated for 2.5 hours at $30^{\circ} \mathrm{C}$ before addition of stop solution $\left(2 \% \mathrm{Na}_{2} \mathrm{CO}_{3}, \mathrm{pH} 11\right)$. The activity was determined as described above.

For determination of the activities in benchmarks, the genes of CbhI (an exoglucanase of T. reesei), EgIII (an endoglucanse of $T$. reesei) and BglI (a $\beta$-glucosidase of A. niger) were also cloned into the pPICZ A vector and transformed in the Pichia expression system. The primers of these genes were derived from the sequences at the NCBI. Cloning and construction were carried out the same way as for W5 genes. The calculation of specific activity in each cellulase candidate was derived from the raw-read/protein concentration. Then the activities of these cellulases were used as controls to derive relatively specific activity of W5 enzymes for exoglucanse (4-MUC), endoglucanase (dye-CMC) and $\beta$-glucosidase ( $p$ NPG), respectively.

\section{Additional material}

Additional file 1: MASCOT results of BLAST homology search of 24 cellulase-like proteins in fungal species in the SwissProt database.

Additional file 2: Categorization of the 219 glycosyl hydrolase-like contigs and their expression levels by Reads Per Kilobase of exon model per million mapped reads (RPKM) value.

\section{Abbreviations}

4-MUC: 4-methylumbelliferyl- $\beta$-cellobiose; BGLU: $\beta$-glucosidase; CAZy: Carbohydrate-Active enZYmes database; CBP: consolidated bioprocess; CMC: carboxylmethyl cellulose; dye-CMC: dye CM-cellulose; EG: endoglucanase; EXG: exoglucanase; GH: glycosyl hydrolase; LC: liquid chromatography; $p N P G$ : p-nitrophenyl- $\beta$-D-glucopyranoside; RPKM: Reads Per Kilobase of exon model per Million mapped reads; RT-PCR: reverse transcriptase-polymerase chain reaction.

\section{Acknowledgements}

Mass spectrometric protein identifications were conducted by the Proteomics Core Lab (Institute of Plant and Microbial Biology and the 
Agricultural Biotechnology Research Center, Academia Sinica, Taipei, Taiwan). We thank the Sequencing Core Facility, Scientific Instrument Center, at Academia Sinica for DNA sequencing. Special thanks to Dr Shyi-Kae Yen and Mr Min-Lang Chang for providing feedstock raw materials. This study was supported by grants from the National Science Council (NSC 96-3114-P-001004-Y, NSC 97-3114-P-001-001, NSC99-3113-B-001-001 and NSC 99-2321-B001-041-MY2) and Academia Sinica, Taipei, Taiwan.

\section{Author details}

'Biodiversity Research Center, Academia Sinica, Taipei 115, Taiwan. ${ }^{2}$ Genomics Research Center, Academia Sinica, Taipei 115, Taiwan. ${ }^{3}$ Graduate Institute of Biotechnology, National Pingtung University of Science \& Technology, Neipu Hsiang, Pingtung 91201, Taiwan. ${ }^{4}$ Department of Life Sciences, National Cheng Kung University, Tainan 701, Taiwan. ${ }^{5}$ Molecular and Biological Agricultural Sciences Program, Taiwan International Graduate Program, National Chung-Hsing University - Academia Sinica, Taipei 115, Taiwan. ${ }^{6}$ Graduate Institute of Biotechnology, National Chung-Hsing University, Taichung 402, Taiwan. ${ }^{7}$ Agricultural Biotechnology Research Center, Academia Sinica, Taipei 115, Taiwan. ${ }^{8} \mathrm{PhD}$ Program in Microbial Genomics, National Chung Hsing University, Taichung 402, Taiwan. ${ }^{9}$ Department of Life Sciences, National Taiwan University, Taipei 106, Taiwan. ${ }^{10}$ Institute of Information Science, Academia Sinica, Taipei 115, Taiwan. ${ }^{11}$ Department of Computer Science and Information Engineering, National Taiwan Normal University, Taipei 116, Taiwan. ${ }^{12}$ Biotechnology Center, National Chung-Hsing University, Taichung 402, Taiwan. ${ }^{13}$ Department of Ecology and Evolution, University of Chicago, Chicago, IL 60637, USA.

\section{Authors' contributions}

TYW, HLC, MYJL, YCC and HMS designed, coordinated and performed some of the experiments and/or analyses and also wrote the manuscript. WHL and $\mathrm{MCH}$ supervised the research and helped to draft and revise the manuscript. CTM, SKR, YCW, HYC HKM, KYH and YWT performed the culturing, cloning and functional experiments. CKC, YHC, JYL and SPC performed next-generation sequencing experiments. TYH, TCC and ACCS performed bioinformatics analyses. All authors read and approved the final manuscript.

\section{Competing interests}

The authors declare that they have no competing interests.

Received: 7 May 2011 Accepted: 17 August 2011

Published: 17 August 2011

\section{References}

1. Paul SS, Kamra DN, Sastry VR, Sahu NP, Agarwal N: Effect of anaerobic fungi on in vitro feed digestion by mixed rumen microflora of buffalo. Reprod Nutr Dev 2004, 44:313-319.

2. Teunissen MJ, de Kort GV, Op den Camp HJ, Vogels GD: Production of cellulolytic and xylanolytic enzymes during growth of anaerobic fungi from ruminant and nonruminant herbivores on different substrates. Appl Biochem Biotechnol 1993, 39-40:177-189.

3. Thareja A, Puniya AK, Goel G, Nagpal R, Sehgal JP, Singh PK, Singh K: In vitro degradation of wheat straw by anaerobic fungi from small ruminants. Arch Anim Nutr 2006, 60:412-417.

4. Tripathi VK, Sehgal JP, Puniya AK, Singh K: Hydrolytic activities of anaerobic fungi from wild blue bull (Boselaphus tragocamelus). Anaerobe 2007, 13:36-39.

5. Teunissen MJ, Smits AA, Op den Camp HJ, Huis in 't Veld JH, Vogels GD: Fermentation of cellulose and production of cellulolytic and xylanolytic enzymes by anaerobic fungi from ruminant and non-ruminant herbivores. Arch Microbiol 1991, 156:290-296.

6. Teunissen MJ, Kets EP, Op den Camp HJ, Huis in 't Veld JH, Vogels GD: Effect of coculture of anaerobic fungi isolated from ruminants and nonruminants with methanogenic bacteria on cellulolytic and xylanolytic enzyme activities. Arch Microbiol 1992, 157:176-182.

7. Teunissen MJ, Op den Camp HJ: Anaerobic fungi and their cellulolytic and xylanolytic enzymes. Antonie Van Leeuwenhoek 1993, 63:63-76.

8. Pai CK, Wu ZY, Chen MJ, Zeng YF, Chen JW, Duan CH, Li ML, Liu JR: Molecular cloning and characterization of a bifunctional xylanolytic enzyme from Neocallimastix patriciarum. Appl Microbiol Biotechnol 2010, 85:1451-1462.
9. Dashtban M, Schraft H, Qin W: Fungal bioconversion of lignocellulosic residues; opportunities \& perspectives. Int J Biol Sci 2009, 5:578-595.

10. Garcia-Campayo V, Wood TM: Purification and characterisation of a $\beta-D-$ xylosidase from the anaerobic rumen fungus Neocallimastix frontalis. Carbohydr Res 1993, 242:229-245.

11. Gomez de Segura B, Fevre M: Purification and characterization of two 1,4$\beta$-xylan endohydrolases from the rumen fungus Neocallimastix frontalis. Appl Environ Microbiol 1993, 59:3654-3660.

12. Gomez de Segura B, Durand R, Fevre M: Multiplicity and expression of xylanases in the rumen fungus Neocallimastix frontalis. FEMS Microbiol Lett 1998, 164:47-53.

13. Hebraud M, Fevre M: Purification and characterization of an aspecific glycoside hydrolase from the anaerobic ruminal fungus Neocallimastix frontalis. Appl Environ Microbiol 1990, 56:3164-3169.

14. Hebraud M, Fevre M: Purification and characterization of an extracellular $\beta$-xylosidase from the rumen anaerobic fungus Neocallimastix frontalis. FEMS Microbiol Lett 1990, 60:11-16.

15. Li XL, Calza RE: Kinetic study of a cellobiase purified from Neocallimastix frontalis EB188. Biochim Biophys Acta 1991, 1080:148-154.

16. Mountfort DO, Asher RA: Production of xylanase by the ruminal anaerobic fungus Neocallimastix frontalis. Appl Environ Microbiol 1989, 55:1016-1022.

17. Pearce PD, Bauchop T: Glycosidases of the rumen anaerobic fungus Neocallimastix frontalis grown on cellulosic substrates. Appl Environ Microbiol 1985, 49:1265-1269.

18. Wood TM, Wilson CA, McCrae SI: The cellulase system of the anaerobic rumen fungus Neocallimastix frontalis: studies on the properties of fractions rich in endo-(1ष4)- $\beta$-D-glucanase activity. Appl Microbiol Biotechnol 1995, 44:177-184.

19. Chen YC, Hseu RS, Cheng KJ: The genetic similarity of different generations of Neocallimastix frontalis SK. FEMS Microbiol Lett 2003, 221:227-231.

20. Black GW, Hazlewood GP, Xue GP, Orpin CG, Gilbert HJ: Xylanase B from Neocallimastix patriciarum contains a non-catalytic 455-residue linker sequence comprised of 57 repeats of an octapeptide. Biochem J 1994, 299:381-387.

21. Cybinski DH, Layton I, Lowry JB, Dalrymple BP: An acetylxylan esterase and a xylanase expressed from genes cloned from the ruminal fungus Neocallimastix patriciarum act synergistically to degrade acetylated xylans. Appl Microbiol Biotechnol 1999, 52:221-225.

22. Dalrymple BP, Cybinski DH, Layton I, McSweeney CS, Xue GP, Swadling YJ, Lowry JB: Three Neocallimastix patriciarum esterases associated with the degradation of complex polysaccharides are members of a new family of hydrolases. Microbiology 1997, 143:2605-2614.

23. Denman S, Xue GP, Patel B: Characterization of a Neocallimastix patriciarum cellulase CDNA (celA) homologous to Trichoderma reesei cellobiohydrolase II. Appl Environ Microbio/ 1996, 62:1889-1896.

24. Lee JM, Hu Y, Zhu H, Cheng KJ, Krell PJ, Forsberg CW: Cloning of a xylanase gene from the ruminal fungus Neocallimastix patriciarum 27 and its expression in Escherichia coli. Can J Microbiol 1993, 39:134-139.

25. Liu JH, Selinger BL, Tsai CF, Cheng KJ: Characterization of a Neocallimastix patriciarum xylanase gene and its product. Can J Microbiol 1999, 45:970-974.

26. Xue GP, Gobius KS, Orpin CG: A novel polysaccharide hydrolase cDNA (celD) from Neocallimastix patriciarum encoding three multi-functional catalytic domains with high endoglucanase, cellobiohydrolase and xylanase activities. J Gen Microbiol 1992, 138:2397-2403.

27. Xue GP, Orpin CG, Gobius KS, Aylward JH, Simpson GD: Cloning and expression of multiple cellulase cDNAs from the anaerobic rumen fungus Neocallimastix patriciarum in Escherichia coli. J Gen Microbiol 1992, 138:1413-1420.

28. Zhou L, Xue GP, Orpin CG, Black GW, Gilbert HJ, Hazlewood GP: Intronless celB from the anaerobic fungus Neocallimastix patriciarum encodes a modular family A endoglucanase. Biochem J 1994, 297:359-364.

29. Ozcan S, Yildirim V, Kaya L, Albrecht D, Becher D, Hecker M, Ozcengiz G: Phanerochaete chrysosporium soluble proteome as a prelude for the analysis of heavy metal stress response. Proteomics 2007, 7:1249-1260.

30. Wang TY, Chen HL, Li WH, Sung HM, Shih MC: Omics applications to biofuel research. In Biocatalysis and Biomolecular Engineering. Edited by: Hou CT, Shaw JF. New York: John Wiley 2010:265-276. 
31. Huang X, Madan A: CAP3: a DNA sequence assembly program. Genome Res 1999, 9:868-877.

32. Sarachu M, Colet M: wEMBOSS: a web interface for EMBOSS. Bioinformatics 2005, 21:540-541.

33. Marchler-Bauer A, Anderson JB, Chitsaz F, Derbyshire MK, DeWeese-Scott C, Fong JH, Geer LY, Geer RC, Gonzales NR, Gwadz M, He S, Hurwitz DI, Jackson JD, Ke Z, Liebert CA, Liu C, Lu F, Lu S, Marchler GH,

Mullokandov M, Song JS, Tasneem A, Thanki N, Yamashita RA, Zhang D, Zhang N, Bryant SH: CDD: specific functional annotation with the Conserved Domain Database. Nucleic Acids Res 2009, 37(Database issue): D205-D210.

34. Cantarel BL, Coutinho PM, Rancurel C, Bernard T, Lombard V, Henrissat B: The Carbohydrate-Active EnZymes database (CAZy): an expert resource for Glycogenomics. Nucleic Acids Res 2009, 37(Database issue):D233-D238.

35. Mortazavi A, Williams BA, McCue K, Schaeffer L, Wold B: Mapping and quantifying mammalian transcriptomes by RNA-Seq. Nat Methods 2008, 5:621-628

36. Steenbakkers PJ, Li XL, Ximenes EA, Arts JG, Chen H, Ljungdahl LG, Op den Camp HJ: Noncatalytic docking domains of cellulosomes of anaerobic fungi. J Bacteriol 2001, 183:5325-5333.

37. Steenbakkers PJ, Freelove A, Van Cranenbroek B, Sweegers BM, Harhangi HR, Vogels GD, Hazlewood GP, Gilbert HJ, Op den Camp HJ: The major component of the cellulosomes of anaerobic fungi from the genus Piromyces is a family 48 glycoside hydrolase. DNA Sea 2002, 13:313-320.

38. Raghothama S, Simpson PJ, Szabo L, Nagy T, Gilbert HJ, Williamson MP: Solution structure of the CBM10 cellulose binding module from Pseudomonas xylanase A. Biochemistry 2000, 39(5):978-84.

39. Laemmli UK: Cleavage of structural proteins during the assembly of the head of bacteriophage T4. Nature 1970, 227:680-685.

40. Shevchenko A, Wilm M, Vorm O, Mann M: Mass spectrometric sequencing of proteins silver-stained polyacrylamide gels. Anal Chem 1996, 68:850-858.

doi:10.1186/1754-6834-4-24

Cite this article as: Wang et al:: Functional characterization of cellulases identified from the cow rumen fungus Neocallimastix patriciarum W5 by transcriptomic and secretomic analyses. Biotechnology for Biofuels 2011 4:24.

\section{Submit your next manuscript to BioMed Central and take full advantage of:}

- Convenient online submission

- Thorough peer review

- No space constraints or color figure charges

- Immediate publication on acceptance

- Inclusion in PubMed, CAS, Scopus and Google Scholar

- Research which is freely available for redistribution

Submit your manuscript at www.biomedcentral.com/submit 